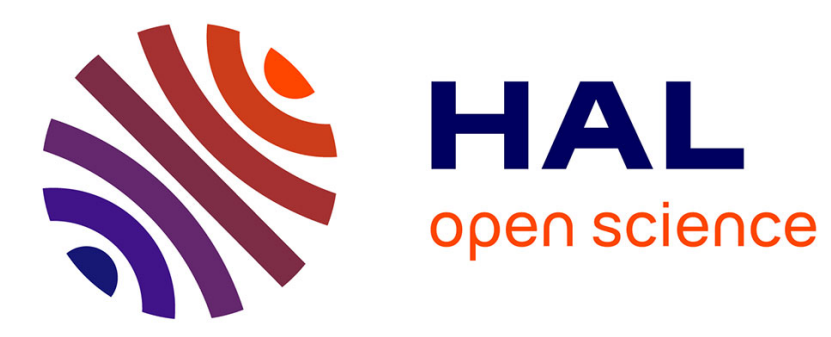

\title{
Polymeric Encapsulation of a Ru(II)-Based Photosensitizer for Folate-Targeted Photodynamic Therapy of Drug Resistant Cancers
}

\author{
Johannes Karges, Mickaël Tharaud, Gilles Gasser
}

\section{- To cite this version:}

Johannes Karges, Mickaël Tharaud, Gilles Gasser. Polymeric Encapsulation of a Ru(II)-Based Photosensitizer for Folate-Targeted Photodynamic Therapy of Drug Resistant Cancers. Journal of Medicinal Chemistry, In press, 10.1021/acs.jmedchem.0c02006 . hal-03190478

\section{HAL Id: hal-03190478 \\ https://hal.science/hal-03190478}

Submitted on 6 Apr 2021

HAL is a multi-disciplinary open access archive for the deposit and dissemination of scientific research documents, whether they are published or not. The documents may come from teaching and research institutions in France or abroad, or from public or private research centers.
L'archive ouverte pluridisciplinaire HAL, est destinée au dépôt et à la diffusion de documents scientifiques de niveau recherche, publiés ou non, émanant des établissements d'enseignement et de recherche français ou étrangers, des laboratoires publics ou privés. 


\section{Polymeric Encapsulation of a Ru(II)-based}

\section{Photosensitizer for Folate Targeted Photodynamic Therapy of Drug Resistant Cancers}

Johannes Kargest, Mickaël Tharaud and Gilles Gasser"**

$\dagger$ Chimie ParisTech, PSL University, CNRS, Institute of Chemistry for Life and Health Sciences, Laboratory for Inorganic Chemical Biology, 75005 Paris, France.

¥ Université de Paris, Institut de Physique du Globe de Paris, CNRS, F-75005 Paris, France.

KEYWORDS: Anticancer, Bioinorganic Chemistry, Medicinal Inorganic Chemistry, Metals in Medicine, Photodynamic Therapy. 


\begin{abstract}
The currently used photodynamic therapy (PDT) photosensitizers (PSs) are generally associated with a poor cancer cell selectivity, which is responsible for some undesirable side effects. To overcome these problems, there is an urgent need for a selective drug delivery system for PDT PSs. Herein, the encapsulation of a promising $\mathrm{Ru}(\mathrm{II})$ polypyridine complex in a polymer with terminal folate groups to form nanoparticles is presented. While the $\mathrm{Ru}$ (II) complex itself has a cytotoxic effect in the dark, the encapsulation is able to overcome this drawback. Upon light exposure, the nanoparticles were found to be highly phototoxic in 2D monolayer cells as well as 3D multicellular tumor spheroids upon $480 \mathrm{~nm}$ or $595 \mathrm{~nm}$ irradiation by apoptosis. Importantly, the nanoparticles demonstrated a high selectivity for cancerous cells over non-cancerous cells and were found to be active in drug resistant cancer cells lines, indicating that they are able to overcome drug resistances.
\end{abstract}




\section{INTRODUCTION}

Cancer is one of the deadliest diseases worldwide. ${ }^{1}$ This disease is commonly treated with the platinum-containing drugs cisplatin, carboplatin and oxaliplatin. Despite their impressive clinical successes, these treatments are associated with severe side effects (e.g., nerve and kidney damage, nausea, vomiting, and bone marrow suppression). ${ }^{2-8}$ Worryingly, an increasing number of tumors in the clinics are reported to be drug resistant. Typically, drug resistance in cancer is associated with tumor burden, growth kinetics, physical barriers, tumor heterogeneity and its microenvironment. ${ }^{9-11}$ To overcome these limitations, there is an urgent need for new types of treatments with new mechanisms of action. ${ }^{12}$

As a complementary technique to classical treatment modalities (i.e., chemotherapy, immunotherapy, radiation therapy), photodynamic therapy (PDT) is currently receiving increasing attention due to its low or non-invasiveness. During a PDT treatment, a photosensitizer (PS) is either locally or systemically injected into a patient. While ideally the PS should not cause any cellular damage in the absence of light, it catalytically generates cytotoxic reactive oxygen species upon light irradiation. The latter ultimately trigger cell death. ${ }^{13-21}$ Among the different types of PSs studied, the use of $\mathrm{Ru}(\mathrm{II})$ polypyridine complexes is receiving increasing attention. ${ }^{22-40}$ Despite their attractive photophysical properties, the majority of these PSs are excited using blue or UVA light. These wavelengths are poorly penetrating tissue, limiting the application of these compounds to superficial treatments. ${ }^{41-45}$ Therefore, there is much research efforts invested towards the development of $\mathrm{Ru}(\mathrm{II})$ polypyridine complexes with an absorption in the biological spectral window $(600-900 \mathrm{~nm})$, which would provide a deeper tissue penetration. ${ }^{46-47}$ In this context, we have recently reported the computational guided design of $\mathrm{Ru}(\mathrm{II})$ polypyridine complexes as PSs for longer wavelengths. Based on this design, we could unveil the metal complex 
$\left[\mathrm{Ru}(4,7\right.$-diphenyl-1,10-phenanthroline)2(4,4'-dimethyl-2,2'-bipyridine) $][\mathrm{PF} 6]_{2}$ (Ru, Figure 1), which exerts a phototoxic effect up to $595 \mathrm{~nm}$. Deeper insights into its mechanism of action revealed that upon irradiation, the $\mathrm{Ru}(\mathrm{II})$ polypyridine complex disturbs mitochondrial respiration and glycolysis processes. Despite these favorable properties, this complex is associated with an undesired dark toxicity in the low micromolar range in various cell lines, limiting its applications as a PDT agent. ${ }^{48}$

After the administration of a PS during a PDT treatment, the target tissue is exposed to light irradiation. As the PS does not cause cellular damage in the dark, the therapeutic effect is only generated upon light exposure. This fact is responsible for the first level of selectivity of PDT. To date, the currently clinically applied and investigated PSs show a poor cancer cell selectivity, accumulating in the tumor as well as in the surrounding, healthy tissue. Due to light scattering effects in the tissue, the light is typically also delivered to healthy tissue, in which the PS may cause significant cellular damage upon light irradiation. This is further emphasized by the fact that it is a practical challenge to expose only tumorous tissue to the light source. This leads to the damage of healthy cells and tissue. To overcome this limitation, there is an urgent need for the development of a cancer selective drug delivery system, which would present a second level of selectivity. The established targeting strategies are typically divided between an active mechanism, which involves the use of a specific cellular interaction (i.e., targeting moieties ${ }^{49-56}$, oligosaccharides $^{57-58}$, nanobodies ${ }^{59}$, oligionucleotides ${ }^{60-61}$, proteins $^{61-64}$ ) or a passive mechanism, which is based on the enhanced permeation and retention (EPR) effect (i.e. nanoparticles ${ }^{65-78}$, polymeric particles $^{79-88}$, liposomes ${ }^{89-90}$, carbon nanotubes $^{91-93}$, metal-organic frameworks ${ }^{94-95}$ ). We note at this stage that the EPR effect is currently controversially discussed due to its failure in in vivo models. ${ }^{96}$ Despite various contributions in the development of delivery systems, these carriers 
are usually associated with a tedious preparation, high price, poor water solubility or a diminished therapeutic effect. To prevail these drawbacks, there is a need for a cheap, water-soluble, and selective drug delivery system.

Encouraged by the promising results reported by our group on the polymeric encapsulation of $\left[\operatorname{Ru}\left(\left(E, E^{\prime}\right)-4,4^{\prime}\right.\right.$-bis $[p$-methoxystyryl $]-2,2^{\prime}$-bipyridine $\left.)\left(2,2^{\prime} \text {-bipyridine }\right)_{2}\right]\left[\mathrm{PF}_{6}\right]_{2} \quad$ with $\quad 1,2-$ distearoyl-sn-glycero-3-phosphoethanolamine- $N$-[biotin (poly-ethyleneglycol)-2000] ammonium salt (DSPE-PEG 2000 -biotin) for biotin-targeted 1- and 2-Photon PDT (Figure 1), ${ }^{97}$ we further explored the potential of this type of delivery system. The previously reported nanoparticles were found to be internalized by an energy-dependent endocytosis mechanism where they preferably accumulate in the lysosomes. Upon irradiation, the encapsulated $\mathrm{Ru}(\mathrm{II})$ polypyridine complexes caused cell death in the low micromolar range through the caspase 3/7 pathway. Promisingly, the nanoformulation was found to lead to a more than 20-times higher accumulation of the $\mathrm{Ru}(\mathrm{II})$ complexes in cancerous adenocarcinomic human alveolar basal epithelial cells than in noncancerous human lung fibroblasts cells. In addition, the cancer targeting effect was also demonstrated in a mouse model. An 8.7 higher accumulation inside the tumor of a mouse model in comparison to the $\mathrm{Ru}(\mathrm{II})$ polypyridine complex itself was observed. Herein, we report the encapsulation of $\mathbf{R u}$ with the analogous polymer with terminal folic acids groups (DSPE-PEG2000folate). While the complex itself exerts an undesired, cytotoxic effect, the formulation is able to overcome this limitation since the nanoparticles were found to be non-toxic in the dark. The particles were found to have a more than eight-times higher selectivity in folate receptor overexpressing cells in comparison to healthy cells. The nanoparticles had a phototoxicity effect in the very low micromolar range upon $480 \mathrm{~nm}$ or $595 \mathrm{~nm}$ excitation in 2D monolayer cancer cells and 3D multicellular tumor spheroids. Importantly, they were also found to be phototoxic in the 
corresponding drug resistant cancer cell lines, indicating that they are able to overcome drug resistance.

\section{RESULTS AND DISCUSSION}

The $\mathrm{Ru}(\mathrm{II})$ polypyridine complex $\left[\mathrm{Ru}(4,7 \text {-diphenyl-1,10-phenanthroline })_{2}\left(4,4^{\prime}\right.\right.$-dimethyl-2,2'bipyridine $)]\left[\mathrm{PF}_{6}\right]_{2}\left(\mathbf{R u}\right.$, Figure 1) was synthesized as previously reported. ${ }^{48}$ The purity of the compound $\geq 95 \%$ as determined by elemental and HPLC analysis (Figure S1). For encapsulation of the lipophilic $\mathrm{Ru}(\mathrm{II})$ polypyridine complex, the commercially available polymer 1,2-distearoylsn-glycero-3-phosphoethanolamine- $N$-[folate(polyethylene glycol)-2000][ammonium salt] (DSPE-PEG 2000 -folate) consisting of a lipophilic part (Figure 1, blue) and hydrophilic part (Figure 1, green) was used for encapsulation into the nanoformulation NP. Based on the difference in water solubility between the two parts, the polymer is able to form micelles in an aqueous solution, which can be loaded with lipophilic compounds. Folate groups (Figure 1, red) were attached on the end of the hydrophilic part. As a variety of cancer cells overexpress folate receptors as well as the high demand for folate in rapidly growing cells, the conjugation to folate could provide an additional cancer targeting effect. ${ }^{98-100}$ Overall, the cancer targeting strategy described here is based on a passive mechanism of the nanoparticles through the EPR effect as well as an active mechanism of folate, which acts as a targeting moiety. The $\mathrm{Ru}(\mathrm{II})$ polypyridine complex was encapsulated as previously described. ${ }^{101-103}$ The amount of encapsulated metal complex was determined using inductively coupled plasma mass spectrometry (ICP-MS). The generated particles were found to have an average size of $122 \mathrm{~nm}$ (size distribution: Figure S2) as determined by dynamic light 
scattering (DLS). Recent studies have shown that this size is optimal for drug delivery due to the high loading of the compound in the particles while still showing a high cellular uptake. ${ }^{104-105}$

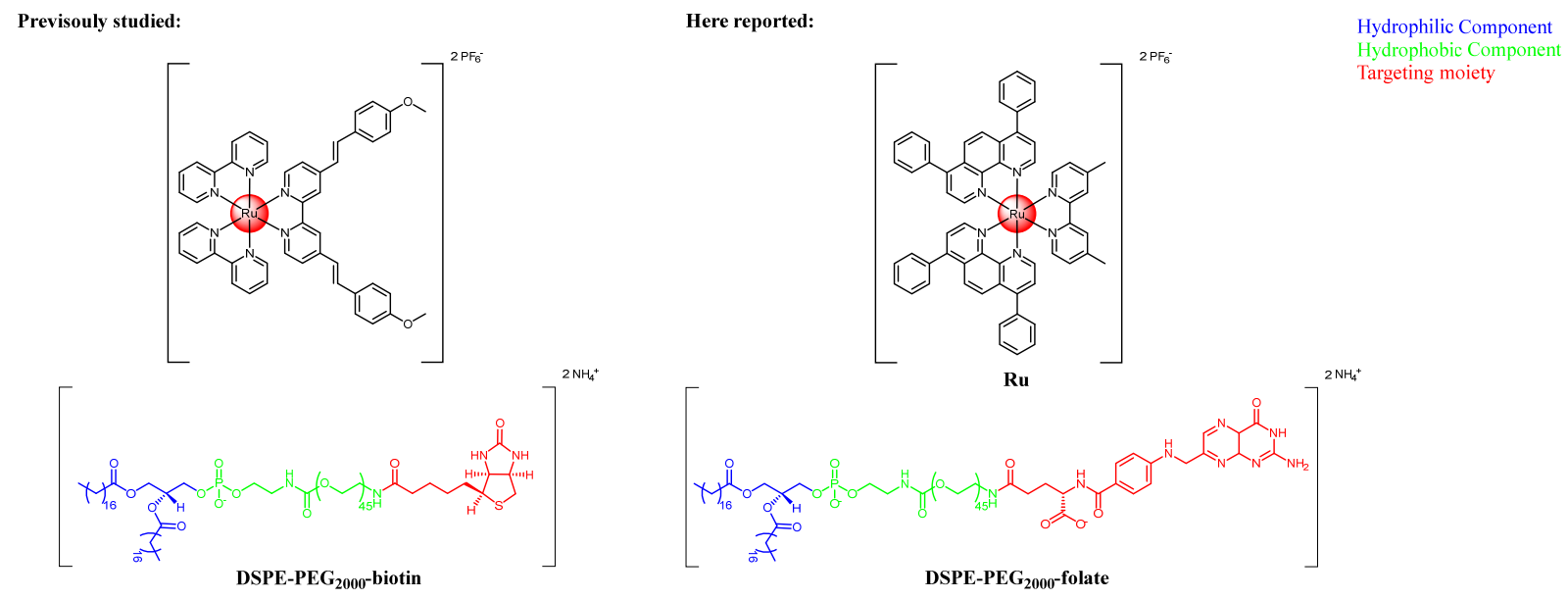

Figure 1. Chemical structures of the previously studied and here reported $\mathrm{Ru}(\mathrm{II})$ polypyridine complexes and polymers used for nanoparticle formulations. The hydrophilic (blue) and lipophilic (green) parts as well as folate (red) are marked in colour.

The photophysical properties of $\mathbf{R u}$ and $\mathbf{N P}$ were investigated to determine whether the encapsulation changed these properties. As expected, the absorption and emission spectra of the $\mathrm{Ru}(\mathrm{II})$ polypyridine complex and the corresponding nanoformulation were found to be identical (Figure S3-S4). The complex showed an absorption tail towards the biological spectral window, which is a desired property for a PDT agent to treat deep-seated or large tumors. Emission studies showed that NP has a significantly higher luminescence quantum yield in an aqueous solution than $\mathbf{R u}\left(\Phi_{\mathrm{em}, \mathrm{Ru}}=1.1 \%, \Phi_{\mathrm{em}, \mathrm{NP}}=2.9 \%\right) . \mathbf{R u}$ and $\mathbf{N P}$ were found to have excited state lifetimes in the nanosecond scale (Table S1, Figure S5-S6). These values compare well with those found for other $\mathrm{Ru}(\mathrm{II})$ polypyridine complexes. ${ }^{106-107}$ Importantly, the presence of air drastically decreased the 
lifetime $\left(\tau_{\text {air }, \mathrm{Ru} / \mathrm{NP}}=128-151 \mathrm{~ns}, \tau_{\text {degassed,Ru/NP }}=857-914 \mathrm{~ns}\right)$, indicating that the excited state of the complex is able to interact with molecular oxygen $\left({ }^{3} \mathrm{O}_{2}\right)$ by generating singlet oxygen $\left({ }^{1} \mathrm{O}_{2}\right)$. Following this, the amount of ${ }^{1} \mathrm{O}_{2}$ produced upon irradiation at $450 \mathrm{~nm}$ or $540 \mathrm{~nm}$ was determined by temporal monitoring the change of absorption of a ${ }^{1} \mathrm{O}_{2}$ scavenger. ${ }^{108-109} \mathrm{NP}$ (Table S2) was found to have a slightly higher singlet oxygen quantum yield than $\mathbf{R u}\left(\Phi_{1 \mathrm{O} 2, \mathrm{Ru}}=5-6 \%, \Phi_{1 \mathrm{O} 2, \mathrm{NP}}=\right.$ $7-10 \%)$. Overall, these results indicate that the encapsulation of the metal complex into nanoparticles enhanced the photophysical properties. Worthy of note, previous studies of the encapsulation of $\mathrm{Ru}(\mathrm{II})$ polypyridine complexes into polymeric particles also reported this effect. $^{80,110}$

Following this, the stability of the nanoparticles was investigated as previous studies have shown that the stability of a metal complex ${ }^{111}$ and/or the nanoformulation ${ }^{79}$ could be problematic. NP was incubated in the dark and its absorption spectra (Figure S7) as well as the size distribution (Figure S8) measured in constant time intervals up to 7 days. As no significant differences were observed, the stability of the nanoparticles is indicated. In addition, the zeta potential of NP was determined to be $-11.8 \mathrm{mV}$, indicating that the particles have a slightly negative charged surface. Previous studies have found that this has a favorable effect on the stability of the particles. ${ }^{12}$

After evaluation of the photophysical properties and establishment of the stability of the nanoparticles, the efficacy of NP to act as a PDT agent was investigated upon irradiation at 480 $\mathrm{nm}\left(10 \mathrm{~min}, 3.1 \mathrm{~J} / \mathrm{cm}^{2}\right)$ and $595 \mathrm{~nm}\left(60 \mathrm{~min}, 11.3 \mathrm{~J} / \mathrm{cm}^{2}\right)$ and compared with $\mathbf{R u}$ (Table 1). The cytotoxic effect of the particles was evaluated while strictly keeping them in the dark, referred to as dark toxicity, as well as upon exposure to a light source, referred to as phototoxicity. As the particles have covalently bound folate groups on the outer surface, the biological effect was investigated on cancerous human ovarian carcinoma (A2780) and its corresponding cisplatin 
resistant (A2780 CIS) and doxorubicin resistant (A2780 ADR) cell lines, which are well known to overexpress the folate receptor alpha $(0.8 \mathrm{pmol} / \mathrm{mg})^{113}$ in comparison to non-cancerous human normal lung fibroblast (MRC-5) cells, which have a level of the folate receptor alpha in the normal range $(0.6 \mathrm{pmol} / \mathrm{mg})^{114-115}$. Interestingly, while $\mathbf{R u}$ exerts a toxicity in the dark in the micromolar range $\left(\mathrm{IC}_{50}=4.17-9.53 \mu \mathrm{M}\right)$, the corresponding nanoformulation NP did not show any toxicity in the dark $\left(\mathrm{IC}_{50}>100 \mu \mathrm{M}\right)$. This demonstrates that the encapsulation of the $\mathrm{Ru}(\mathrm{II})$ polypyridine complex drastically decreased undesired dark toxicity. Upon irradiation at $480 \mathrm{~nm}$ and $595 \mathrm{~nm}$, a phototoxic effect in the micromolar range for $\mathbf{R u}\left(\mathrm{IC}_{50}=0.27-0.72 \mu \mathrm{M}\right)$ and $\mathbf{N P}\left(\mathrm{IC}_{50}=2.64-\right.$ $63.8 \mu \mathrm{M}$ ) with high phototoxic indices (PI) for NP of up to $>37.9$ were observed. The cytotoxic values for NP in A2780 cells and its drug resistant versions were found to be identical, indicating that the PDT treatment with NP is able to overcome drug resistances. Strikingly, while (photo)toxic values were found to be similar for $\mathbf{R u}$ in the different cell lines, the treatment with $\mathbf{N P}$ showed significant different values. The nanoparticles were found to have a significantly higher phototoxicity in the ovarian cancer cell lines $\left(\mathrm{IC}_{50}=2.64-3.92 \mu \mathrm{M}\right)$, which are overexpressing the folate receptor, compared to the lung fibroblast cell line $\left(\mathrm{IC}_{50}=40.51-63.83 \mu \mathrm{M}\right)$, which has a normal level of the folate receptors, suggesting a folate targeting effect. 
Table 1. IC 50 values (in $\mu \mathrm{M})$ in the dark and upon irradiation at $480\left(10 \mathrm{~min}, 3.1 \mathrm{~J} / \mathrm{cm}^{2}\right)$ and $595 \mathrm{~nm}\left(60 \mathrm{~min}, 11.3 \mathrm{~J} / \mathrm{cm}^{2}\right)$ for $\mathbf{R u}$ and NP in comparison to cisplatin and the PS Protoporphyrin IX (PpIX) in non-cancerous MRC-5 (human normal lung fibroblast) and cancerous human ovarian carcinoma (A2780), cisplatin resistant ovarian carcinoma (A2780 CIS) and human doxorubicin resistant ovarian carcinoma (A2780 ADR) cells. Average of three independent measurements.

\begin{tabular}{|c|c|c|c|c|c|c|c|c|c|c|c|c|c|c|c|c|c|c|c|c|}
\hline & \multicolumn{5}{|c|}{ MRC-5 } & \multicolumn{5}{|c|}{$\mathbf{A 2 7 8 0}$} & \multicolumn{5}{|c|}{ A2780 CIS } & \multicolumn{5}{|c|}{ A2780 ADR } \\
\hline & dark & $\begin{array}{l}480 \\
\mathrm{~nm}\end{array}$ & PI & $\begin{array}{l}595 \\
\mathrm{~nm}\end{array}$ & PI & dark & $\begin{array}{l}480 \\
\mathrm{~nm}\end{array}$ & PI & $\begin{array}{l}595 \\
\mathrm{~nm}\end{array}$ & PI & dark & $\begin{array}{l}480 \\
\mathrm{~nm}\end{array}$ & PI & $\begin{array}{l}595 \\
\mathrm{~nm}\end{array}$ & PI & dark & $\begin{array}{l}480 \\
\mathrm{~nm}\end{array}$ & PI & $\begin{array}{l}595 \\
\mathrm{~nm}\end{array}$ & PI \\
\hline Ru & $\begin{array}{c}4.17 \\
\pm \\
0.36\end{array}$ & $\begin{array}{c}0.27 \pm \\
0.12\end{array}$ & 15.4 & $\begin{array}{c}0.46 \pm \\
0.17\end{array}$ & 9.1 & $\begin{array}{c}8.39 \\
\pm \\
0.76\end{array}$ & $\begin{array}{c}0.44 \pm \\
0.09\end{array}$ & 19.1 & $\begin{array}{c}0.67 \pm \\
0.18\end{array}$ & 12.5 & $\begin{array}{c}9.76 \pm \\
0.88\end{array}$ & $\begin{array}{c}0.51 \pm \\
0.10\end{array}$ & 19.1 & $\begin{array}{c}0.63 \pm \\
0.08\end{array}$ & 15.5 & $\begin{array}{c}9.53 \\
\pm \\
0.60\end{array}$ & $\begin{array}{c}0.55 \pm \\
0.11\end{array}$ & 17.3 & $\begin{array}{c}0.72 \pm \\
0.15\end{array}$ & 13.2 \\
\hline $\mathbf{N P}$ & $>100$ & $\begin{array}{c}40.51 \\
\pm \\
2.79\end{array}$ & $>2.5$ & $\begin{array}{c}63.83 \\
\pm \\
5.40\end{array}$ & $>1.6$ & $>100$ & $\begin{array}{c}2.64 \\
\pm \\
0.33\end{array}$ & $>37.9$ & $\begin{array}{c}3.51 \\
\pm \\
0.64\end{array}$ & $>28.5$ & $>100$ & $\begin{array}{c}2.83 \\
\pm \\
0.67\end{array}$ & $>35.3$ & $\begin{array}{c}3.75 \\
\pm \\
0.71\end{array}$ & $>26.7$ & $>100$ & $\begin{array}{c}2.71 \\
\pm \\
0.49\end{array}$ & $>36.9$ & $\begin{array}{c}3.92 \pm \\
0.74\end{array}$ & $>25.5$ \\
\hline PpIX & $>100$ & $\begin{array}{c}6.19 \\
\pm \\
0.74\end{array}$ & $>16.2$ & $\begin{array}{c}16.73 \\
\pm \\
1.21\end{array}$ & $>6.0$ & $>100$ & $\begin{array}{c}4.53 \\
\pm \\
0.61\end{array}$ & $>22.1$ & $\begin{array}{c}8.19 \\
\pm \\
1.13\end{array}$ & $>12.2$ & $>100$ & $\begin{array}{c}6.95 \\
\pm \\
1.46\end{array}$ & $>14.4$ & $\begin{array}{c}8.94 \\
\pm \\
1.53\end{array}$ & $>11.2$ & $>100$ & $\begin{array}{c}7.12 \\
\pm \\
1.96\end{array}$ & $>14.0$ & $\begin{array}{c}10.38 \\
\pm \\
1.62\end{array}$ & $>9.6$ \\
\hline cisplatin & $\begin{array}{c}12.93 \\
\pm \\
0.86\end{array}$ & - & - & - & - & $\begin{array}{c}4.54 \\
\pm \\
0.65\end{array}$ & - & - & - & - & $\begin{array}{c}19.53 \pm \\
1.11\end{array}$ & - & - & - & - & $\begin{array}{c}8.97 \\
\pm \\
0.71\end{array}$ & - & - & - & - \\
\hline
\end{tabular}


Following this promising observation, the uptake of NP $(25 \mu \mathrm{M}, 4 \mathrm{~h})$ in A2780 and MRC-5 cells was investigated by determination of the amount of Ru inside cells using ICP-MS. As expected, in the folate receptor overexpressing cell line A2780, a more than eight-times higher amount of Ru was detected compared to MRC-5 (Figure 2). It is important to mention that A2780 and MRC5 cells are inherently different types of cells with different properties and therefore different cellular uptake. Further, the amount of covalently attached folic acid targeting moieties on the outer surface of the nanoparticles is order of magnitudes higher than the amount of available folate receptors in the tested cell lines.

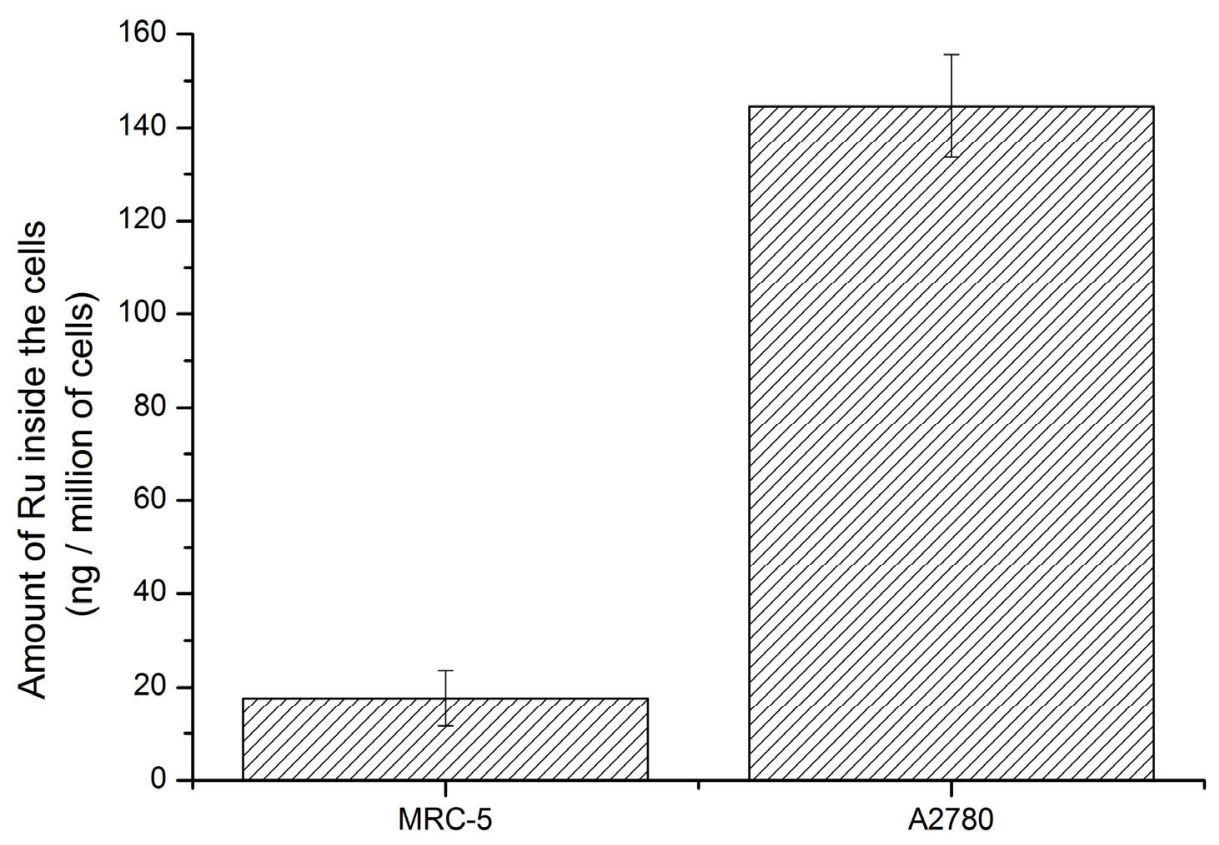

Figure 2. Uptake of NP ( $25 \mu \mathrm{M}, 4 \mathrm{~h})$ in MRC-5 and A2780 cells. The uptake was determined by measurement of the amount of Ru inside the cells using ICP-MS. 
The localization of NP inside of A2780 cells was then examined by extraction of the different cellular compartments (i.e., nucleus, mitochondria, lysosomes, Golgi apparatus, endoplasmic reticulum) and determination of the amount of $\mathrm{Ru}$ inside each organelle by ICP-MS. The compound was mainly found in the lysosomes (Figure 3), like other metal complexes and organic molecules, which were encapsulated with a DSPE-PEG2000 polymer. $^{101-103}$

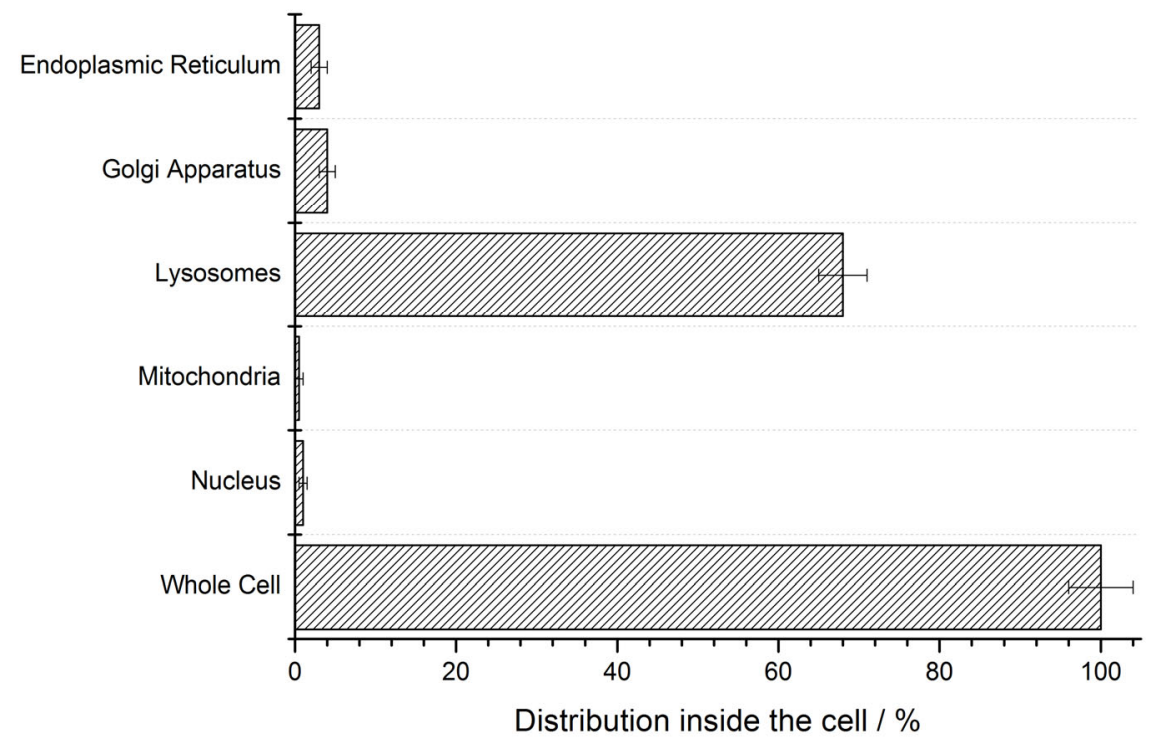

Figure 3. Cellular distribution of NP $(20 \mu \mathrm{M}, 4 \mathrm{~h})$ in A2780 cells by extraction of the cellular organelles and determination of the amount of Ru inside each organelle by ICP-MS.

For a deeper insight into the mechanism of action, the cell death mechanism of NP $(2.64 \mu \mathrm{M})$ upon irradiation at $480 \mathrm{~nm}\left(10 \mathrm{~min}, 3.1 \mathrm{~J} / \mathrm{cm}^{2}\right)$ in A2780 cells was investigated. The cell survival upon pre-treatment with autophagy (3-methyladenine), apoptosis (Z-VAD-FMK), paraptosis (cycloheximide) or necrosis (necrostatin-1) inhibitors was measured. As the incubation with autophagy, paraptosis and necrosis inhibitors did not significantly influence the cell survival 
(Figure 4a), these cell death pathways were ruled out. In contrast, the preincubation with an apoptosis inhibitor strongly increased the survival of the cells, indicating that cell death is primary caused by apoptosis. Worthy of note, the majority of PDT agents were found to cause cell death by apoptosis. ${ }^{116}$ As many apoptotic processes are controlled by caspases ${ }^{117}$, the dependency on the caspase 3/7 pathway was investigated using a Caspase-Glo 3/7 assay. The light treatment showed a highly increased caspase activity similar to the kinase inhibitor staurosporin, which is well known to act by this pathway, indicating that the phototoxic effect exerted by NP is caused by the caspase 3/7 pathway (Figure $4 b$ ). Worthy of note, previous studies of $\mathrm{Ru}(\mathrm{II})$ polypyridine complexes were found to cause cell death by the same mechanism. ${ }^{118-119}$
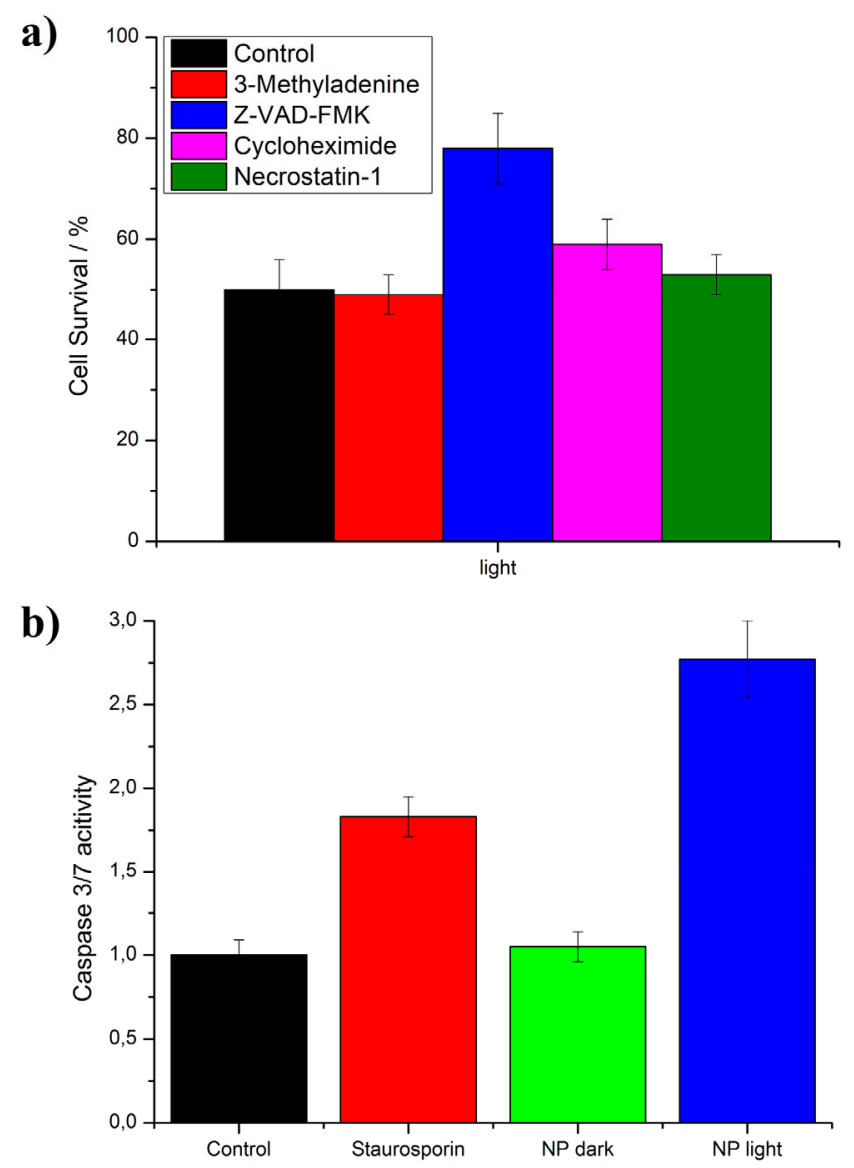
Figure 4. Study of the cell death mechanism of NP in A2780 cells upon irradiation at $480 \mathrm{~nm}$ (10 $\min , 3.1 \mathrm{~J} / \mathrm{cm}^{2}$ ) a) upon pre-incubation of different inhibitors and determination of the cell survival. Autophagy inhibitor: 3-Methyladenine $(100 \mu \mathrm{M})$, apoptosis inhibitor: Z-VAD-FMK $(20 \mu \mathrm{M})$, paraptosis inihibitor: Cycloheximide $(0.1 \mu \mathrm{M})$, necrosis inihibitor: Necrostatin-1 $(60 \mu \mathrm{M})$. b) upon determination of the caspase $3 / 7$ activity.

Following the evaluation in 2D monolayer cells, the biological effects were further investigated in 3D multicellular tumor spheroids (MCTS). MCTS are a tissue model to simulate the pathological conditions found in clinical tumors including proliferation gradients and a hypoxic center. ${ }^{120-121}$ As the majority of PSs act by an oxygen dependent mechanism, the treatment of hypoxic tumors remains a major medical challenge. ${ }^{122-124}$ Many investigated drug candidates have failed the translation to in vivo models due to compromised drug delivery. ${ }^{125-126}$ MCTS are able to mimic intercellular interactions and are therefore employed to investigate the drug delivery of compounds. However, we note that such experiments do not help assessing the folate targeting ability of the NPs. In this work, A2780 MCTSs with a diameter of $400 \mu \mathrm{m}$ were incubated with NP for $12 \mathrm{~h}$ and their cytotoxicity assessed by measurement of the ATP concentration. Promisingly, the nanoparticles did not show a cytotoxic effect in the dark $\left(\mathrm{IC}_{50}>100 \mu \mathrm{M}\right)$, which is an important requirement for a PDT agent. On the contrary, upon irradiation at $480 \mathrm{~nm}$ (10 min, $\left.3.1 \mathrm{~J} / \mathrm{cm}^{2}\right)$ and $595 \mathrm{~nm}\left(60 \mathrm{~min}, 11.3 \mathrm{~J} / \mathrm{cm}^{2}\right), \mathbf{N P}$ was found to have a high phototoxic effect $\left(\mathrm{IC}_{50,480 \mathrm{~nm}}=8.16 \pm 0.87 \mu \mathrm{M}, \mathrm{PI}_{480 \mathrm{~nm}}>12.3, \mathrm{IC}_{50,595 \mathrm{~nm}}=9.62 \pm 0.93 \mu \mathrm{M}, \mathrm{PI}_{595 \mathrm{~nm}}>10.4\right)$. This indicates that NP is able to penetrate a 3D MCTS and to act as a PDT agent from $480 \mathrm{~nm}$ up to $595 \mathrm{~nm}$. 


\section{CONCLUSION}

In summary, the encapsulation of a promising $\mathrm{Ru}(\mathrm{II})$ polypyridine complex (Ru) with the amphiphilic polymer DSPE-PEG 2000 -folate is described. The generated particles (NP) showed improved photophysical properties in comparison to the complex alone in an aqueous solution. While the complex itself has a dark toxicity in various cell lines, the nanoformulation described in this article is able to overcome this drawback. Upon irradiation from $480 \mathrm{~nm}$ up to $595 \mathrm{~nm}$, NP caused cell death in the low micromolar range in $2 \mathrm{D}$ monolayer cells as well as $3 \mathrm{D}$ multicellular tumor spheroids by apoptosis through the caspase $3 / 7$ pathway. ICP-MS studies showed that the particles accumulated in the lysosomes and, very importantly, much more in cancer cells overexpressing the folate receptor, therefore confirming a cancer targeting effect. NP could overcome drug resistances, which are observed in many clinical tumors. We strongly believe that this class of compounds as well as their corresponding particles have a great potential for the development of cancer targeted PDT agents.

\section{EXPERIMENTAL SECTION}

\section{Instrumentation and methods}

${ }^{1} \mathrm{H}$ and ${ }^{13} \mathrm{C}$ NMR spectra were recorded on a Bruker $400 \mathrm{MHz}$ NMR spectrometer. For analytic HPLC the following system has been used: 2 x Agilent G1361 1260 Prep Pump system with Agilent G7115A 1260 DAD WR Detector equipped with an Agilent Pursuit XRs 5C18 (100 A, C18 $5 \mu \mathrm{m} 250 \times 4.6 \mathrm{~mm}$ ) Column and an Agilent G1364B 1260-FC fraction collector. The flow 
rate was $1 \mathrm{~mL} / \mathrm{min}$ and the chromatogram was detected at $250 \mathrm{~nm}$. The solvents (HPLC grade) were millipore water $(0.1 \%$ TFA, solvent $\mathrm{A})$ and acetonitrile (solvent $\mathrm{B})$. 0-3 minutes: isocratic $95 \%$ A (5\% B); 3-17 minutes: linear gradient from $95 \%$ A (5\% B) to $0 \%$ A $(100 \% \mathrm{~B}) ; 17-23$ minutes: isocratic $0 \% \mathrm{~A}(100 \% \mathrm{~B})$. Elemental microanalyses were performed on a Thermo Flash 2000 elemental analyzer. Inductively coupled plasma mass spectrometry (ICP-MS) experiments were carried out on HR-ICP-MS Element II (Thermo Scientific) apparatus. The nanoparticle intensity-based diameter was determined by dynamic light scattering (DLS) and zeta potential using a Malvern ZetaSizer Nano ZS.

\section{Materials}

All chemicals were obtained from commercial sources and were used without further purification. 1,2-distearoyl-sn-glycero-3-phosphoethanolamine- $N$-[folate(polyethylene glycol)2000][ammonium salt] (DSPE-PEG 2000 -folate) was obtained from Avanti Polar Lipids. Dulbecco's Modified Eagles Medium (DMEM/F10 media), Roswell Park Memorial Institute medium (RPMI 1640), Fetal Bovine Serum (FBS), Gibco Penicillin-Streptomycin-Glutamine (Penstrep), Dulbecco's Phosphate-Buffered Saline (PBS) were purchased from Fisher Scientific and Resazurin from ACROS Organics.

\section{Synthesis}

The $\mathrm{Ru}(\mathrm{II})$ polypyridine complex $\left[\mathrm{Ru}(4,7 \text {-diphenyl-1,10-phenanthroline })_{2}\left(4,4^{\prime}\right.\right.$-dimethyl-2,2'bipyridine $)]\left[\mathrm{PF}_{6}\right]_{2}(\mathbf{R u})$ was synthesized as previously reported. ${ }^{48}$ Elemental analysis calcd. for 
$\mathrm{C}_{60} \mathrm{H}_{44} \mathrm{~F}_{12} \mathrm{~N}_{6} \mathrm{P}_{2} \mathrm{Ru}(\%)$ : C 58.12, H 3.58, N 6.78; found: C 58.37, H 3.84, N 6.51. The purity of the compound was found to be $\geq 95 \%$ as determined by HPLC analysis.

\section{Preparation of nanoparticle formulation NP}

A solution of $5 \mathrm{mg}$ of $\mathbf{R u}$ in $0.5 \mathrm{~mL}$ DCM was added to a solution of $10 \mathrm{mg}$ of 1,2-distearoyl-snglycero-3-phosphoethanolamine- $N$-[folate(polyethylene glycol)-2000][ammonium salt] (DSPE$\mathrm{PEG}_{2000}$-folate) in $19.5 \mathrm{~mL} \mathrm{H} \mathrm{H}_{2} \mathrm{O}$. The solution was further treated with ultrasonic pulses while keeping the sample constantly at $25{ }^{\circ} \mathrm{C}$. The DCM was removed by evaporation at $50{ }^{\circ} \mathrm{C}$. Large aggregated were removed by size exclusion chromatography. After that, a clear transparent solution of NP in $\mathrm{H}_{2} \mathrm{O}$ was obtained. The amount of encapsulated complex was determined by ICP-MS as $0.209 \mathrm{mg} / \mathrm{mL}$ (Yield: $84 \%$ ).

\section{Spectroscopic measurements}

The absorption of the samples has been measured with a SpectraMax M2 Spectrometer (Molecular Devices). The emission was measured by irradiation of the sample in fluorescence quartz cuvettes (width $1 \mathrm{~cm}$ ) using a NT342B Nd-YAG pumped optical parametric oscillator (Ekspla) at $450 \mathrm{~nm}$. Luminescence was focused and collected at right angle to the excitation pathway and directed to a Princeton Instruments Acton SP-2300i monochromator. As a detector a XPI-Max 4 CCD camera (Princeton Instruments) has been used.

\section{Luminescence quantum yield measurements}


For the determination of the luminescence quantum yield, the samples were prepared in an $\mathrm{H}_{2} \mathrm{O}$ solution with an absorbance of 0.1 at $450 \mathrm{~nm}$. This solution was irradiated in fluorescence quartz cuvettes (width $1 \mathrm{~cm}$ ) using a NT342B Nd-YAG pumped optical parametric oscillator (Ekspla) at $450 \mathrm{~nm}$. The emission signal was focused and collected at right angle to the excitation pathway and directed to a Princeton Instruments Acton SP-2300i monochromator. As a detector a XPI-Max 4 CCD camera (Princeton Instruments) has been used. The luminescence quantum yields were determined by comparison with the reference $\left[\mathrm{Ru}(\text { bipy })_{3}\right] \mathrm{Cl}_{2}$ in $\mathrm{CH}_{3} \mathrm{CN}\left(\Phi_{\mathrm{em}}=5.9 \%\right)^{127}$ applying the following formula:

$$
\begin{gathered}
\Phi_{\text {em, sample }}=\Phi_{\text {em, reference }} \times\left(F_{\text {reference }} / F_{\text {sample }}\right) \times\left(I_{\text {sample }} / \mathrm{I}_{\text {reference }}\right) \times\left(\mathrm{n}_{\text {sample }} / \mathrm{n}_{\text {reference }}\right)^{2} \\
\mathrm{~F}=1-10^{-\mathrm{A}}
\end{gathered}
$$

$\Phi_{\mathrm{em}}=$ luminescence quantum yield, $\mathrm{F}=$ fraction of light absorbed, $\mathrm{I}=$ integrated emission intensities, $\mathrm{n}=$ refractive index, $\mathrm{A}=$ absorbance of the sample at irradiation wavelength.

\section{Lifetime measurements}

For the determination of the lifetimes, the samples were prepared in an air saturated and in a degassed $\mathrm{H}_{2} \mathrm{O}$ solution with an absorbance of 0.1 at $450 \mathrm{~nm}$. This solution was irradiated in fluorescence quartz cuvettes (width $1 \mathrm{~cm}$ ) using a NT342B Nd-YAG pumped optical parametric oscillator (Ekspla) at $450 \mathrm{~nm}$. The emission signal was focused and collected at right angle to the excitation pathway and directed to a Princeton Instruments Acton SP-2300i monochromator. As a detector a R928 photomultiplier tube (Hamamatsu) has been used. 


\section{Singlet oxygen measurements}

The samples were prepared in an air-saturated aqueous solution containing the complex with an absorbance of 0.1 at the irradiation wavelength, $N, N$-dimethyl-4-nitrosoaniline aniline (RNO, $20 \mu \mathrm{M})$ and histidine $(10 \mathrm{mM})$. The samples were irradiated on 96 well plates with an Atlas Photonics LUMOS BIO irradiator at $450 \mathrm{~nm}$ or $540 \mathrm{~nm}$ for different times. The absorbance of the samples was measured during these time intervals with a SpectraMax M2 Microplate Reader (Molecular Devices). The difference in absorbance $\left(\mathrm{A}_{0}-\mathrm{A}\right)$ at $440 \mathrm{~nm}$ was calculated and plotted against the irradiation times. From the plot the slope of the linear regression was calculated. As reference for the measurement $\left[\mathrm{Ru}(\text { bipy })_{3}\right] \mathrm{Cl}_{2}\left(\Phi_{1 \mathrm{O} 2, \mathrm{Ru}(\text { bipy })_{3} \mathrm{Cl}_{2}}=0.22\right)^{128}$ was used and the singlet oxygen quantum yields were calculated using the following formula:

$$
\begin{gathered}
\Phi_{\text {sample }}=\Phi_{\text {reference }} \times \frac{\mathrm{S}_{\text {sample }}}{\mathrm{S}_{\text {reference }}} \times \frac{\mathrm{I}_{\text {reference }}}{\mathrm{I}_{\text {sample }}} \\
\mathrm{I}=\mathrm{I}_{0} \times\left(1-10^{-A}\right)
\end{gathered}
$$

$\Phi=$ singlet oxygen quantum yield, $\mathrm{S}=$ slope of the linear regression of the plot of the areas of the singlet oxygen luminescence peaks against the irradiation intensity, $\mathrm{I}=$ absorbance correction factor, $\mathrm{I}_{0}=$ light intensity of the irradiation source, $\mathrm{A}=$ absorbance of the sample at irradiation wavelength.

\section{Stability in $\mathrm{H}_{2} \mathrm{O}$}

The stability of $\mathbf{N P}$ in $\mathrm{H}_{2} \mathrm{O}$ was investigated by UV/Vis spectroscopy and dynamic light scattering (DLS). The solution was stored at room temperature in the dark. The absorption spectrum from 
250-600 nm was recorded with a SpectraMax M2 Microplate Reader (Molecular Devices) and the size distribution with a Malvern ZetaSizer Nano ZS after each time interval (0-7 days) and compared.

\section{Cell culture}

Human normal lung fibroblast (MRC-5) cells were cultured in DMEM/F10 media. The human ovarian carcinoma (A2780), human cisplatin resistant ovarian carcinoma (A2780 cis) and human doxorubicin resistant ovarian carcinoma (A2780 ADR) cell lines were cultured in RPMI 1640 media. The resistance of A2780 cis was maintained by cisplatin treatment $(1 \mu \mathrm{M})$ for one week every month. The cells were used in the assays after one week from the end of the treatment in order to avoid interferences in the results. The resistance of A2780 ADR was maintained by doxorubicin treatment $(0.1 \mu \mathrm{M})$ once a week. Cells were used in the assays after three days post doxorubicin treatment in order to avoid interferences in the results. All cell lines were complemented with $10 \%$ of fetal calf serum, $100 \mathrm{U} / \mathrm{mL}$ penicillin-streptomycin mixture and maintained in humidified atmosphere at $37^{\circ} \mathrm{C}$ and $5 \%$ of $\mathrm{CO}_{2}$.

\section{(Photo-)cytotoxicity on 2D monolayer cells}

The cytotoxicity of the complexes was assessed using a fluorometric resazurin assay. The cultivated cells were seeded in triplicates in 96 well plates with a density of 4000 cells per well in $100 \mu \mathrm{L}$ of media. After $24 \mathrm{~h}$, the medium was removed and the cells were treated with increasing concentrations of the complex diluted in cell media achieving a total volume of $200 \mu \mathrm{L}$. The cells 
were incubated with the complex for $4 \mathrm{~h}$. After this time, the media was removed and replaced with $200 \mu \mathrm{L}$ of fresh medium. For the phototoxicity studies, the cells were exposed to light with an Atlas Photonics LUMOS BIO irradiator at $480 \mathrm{~nm}$ (spectral half-width: $20 \mathrm{~nm}, 10 \mathrm{~min}, 3.1$ $\mathrm{J} / \mathrm{cm}^{2}$ ) or $595 \mathrm{~nm}$ (spectral half-width: $20 \mathrm{~nm}, 60 \mathrm{~min}, 11.3 \mathrm{~J} / \mathrm{cm}^{2}$ ). Each well was constantly illuminated. During this time, the temperature was maintained constantly at $37^{\circ} \mathrm{C}$. The cells were grown in the incubator for additional $44 \mathrm{~h}$. For the determination of the dark cytotoxicity, the cells were not irradiated and after the medium exchange directly incubated for $44 \mathrm{~h}$. After this time, the medium was replaced with fresh medium containing resazurin with a final concentration of 0.2 $\mathrm{mg} / \mathrm{mL}$. After $4 \mathrm{~h}$ incubation, the amount of the fluorescent product resorufin was determined upon excitation at $540 \mathrm{~nm}$ and measurement its emission at $590 \mathrm{~nm}$ using a SpectraMax M2 Microplate Reader (Molecular Devices). The obtained data was analyzed with the GraphPad Prism software.

\section{Cellular uptake}

The cellular uptake of the complex was investigated by the determination of the Ru content inside the cells. The complex with a final concentration of $25 \mu \mathrm{M}$ was incubated for $4 \mathrm{~h}$ at $37{ }^{\circ} \mathrm{C}$ on a cell culture dish with a density of ca. $5 \cdot 10^{6}$ cells in $10 \mathrm{~mL}$ of media. After this time, the media was removed and the cells were washed with cell media. The cells were trypsinised, harvested, centrifuged and resuspended. The number of cells on each dish was accurately counted. Each sample was the digested using a $60 \% \mathrm{HNO}_{3}$ solution for three days. The acid was evaporated and the residue dissolved in $2 \% \mathrm{HCl}$ in water. The Ru content was determined using an ICP-MS apparatus and comparing the results with the $\mathrm{Ru}$ references. The $\mathrm{Ru}$ content was then associated with the number of cells. 


\section{Intracellular distribution by ICP-MS}

The co-localisation of the compound was determined by measuring the Ru content inside the cell via ICP-MS. $20 \cdot 10^{6}$ cells were incubated with the compound $(20 \mu \mathrm{M})$ for $4 \mathrm{~h}$ at $37^{\circ} \mathrm{C}$ in the dark. After this time, the cells were detached with trypsin and harvested. The number of cells was accurately counted. The amount was equally divided. In the first portion, the nucleus was extracted using a nucleus extraction kit (Thermo Scientific); in the second portion, the mitochondria was extracted using a mitochondria extraction kit (Thermo Scientific); in the third portion, the lysosome was extracted using a lysosome extraction kit (Sigma Aldrich); in the fourth portion, the golgi apparatus was extracted using a golgi apparatus extraction kit (Sigma Aldrich) and in the fifth portion, the endoplasmic reticulum was extracted using a endoplasmic reticulum extraction kit (Sigma Aldrich). Each sample was digested using a $60 \% \mathrm{HNO}_{3}$ solution for three days. The solution was evaporated and each sample was diluted to solution of $2 \% \mathrm{HCl}$ in water. The $\mathrm{Ru}$ content was determined using an ICP-MS apparatus and comparing the results with the $\mathrm{Ru}$ references. The Ru content was then associated with the number of cells.

\section{Cell death mechanism}

The cell death mechanism assay was investigated using a fluorometric resazurin assay after preincubation with various cell death inhibitors. 3-methyladenine $(100 \mu \mathrm{M})$, Z-VAD-FMK (20 $\mu \mathrm{M})$, cycloheximide $(0.1 \mu \mathrm{M})$ and necrostatin-1 $(60 \mu \mathrm{M})$ were pre-incubated in A2780 cells for 40 min. NP $(2.64 \mu \mathrm{M})$ was then incubated for $4 \mathrm{~h}$. After this time, the media was removed and replaced with $200 \mu \mathrm{L}$ of fresh medium. For the phototoxicity studies, the cells were exposed to 
light with an Atlas Photonics LUMOS BIO irradiator at $480 \mathrm{~nm}$ (spectral half-width: $20 \mathrm{~nm}, 10$ $\min , 3.1 \mathrm{~J} / \mathrm{cm}^{2}$ ). Each well was constantly illuminated and the temperature was maintained at 37 ${ }^{\circ} \mathrm{C}$. The cells were grown in the incubator for additional $44 \mathrm{~h}$. For the determination of the dark cytotoxicity, the cells were not irradiated and after the medium exchange directly incubated for 44 h. After this time, the medium was replaced with fresh medium containing resazurin with a final concentration of $0.2 \mathrm{mg} / \mathrm{mL}$. After $4 \mathrm{~h}$ incubation, the amount of the fluorescent product resorufin was determined upon excitation at $540 \mathrm{~nm}$ and measurement its emission at $590 \mathrm{~nm}$ using a SpectraMax M2 Microplate Reader (Molecular Devices). The obtained data was analyzed with the GraphPad Prism software.

\section{Caspase-3/7 activation}

Caspase-3/7 activity was measured using Caspase-Glo-3/7 assay kit (Promega). The cultivated cells were seeded in triplicates in 96 well plates with a density of 4000 cells per well in $100 \mu \mathrm{L}$ of media. After $24 \mathrm{~h}$, the medium was removed and the cells were treated with $\mathbf{N P}(5.28 \mu \mathrm{M})$ diluted in cell media achieving a total volume of $200 \mu \mathrm{L}$. For the phototoxicity studies, the cells were exposed to light with an Atlas Photonics LUMOS BIO irradiator at $480 \mathrm{~nm}$ (spectral half-width: $20 \mathrm{~nm}, 10 \mathrm{~min}, 3.1 \mathrm{~J} / \mathrm{cm}^{2}$ ). Each well was constantly illuminated and the temperature was maintained at $37{ }^{\circ} \mathrm{C}$. The cells were grown in the incubator for additional $12 \mathrm{~h}$. After this time, Caspase-Glo 3/7 reagent $(100 \mu \mathrm{L})$ was added and the cells incubated for an additional $1 \mathrm{~h}$ in the dark. The generated chemiluminescence was measured using a SpectraMax M2 Microplate Reader (Molecular Devices). 


\section{Generation of 3D multicellular tumor spheroids (MCTS)}

MCTS were cultured using ultra-low attachment 96 wells plates from Corning. The cells were seeded at a density of 4000 cells per well in $200 \mu \mathrm{L}$. The MCTS were cultivated and maintained in a cell culture incubator at $37^{\circ} \mathrm{C}$ with $5 \% \mathrm{CO}_{2}$ atmosphere. The culture media was replaced every two days. Within two-three days MCTs were formed from the cell suspension. The formation as well as integrity and diameter of the MCTs was monitored by light microscopy.

\section{(Photo-)cytotoxicity on 3D multicellular tumor spheroids (MCTS)}

The cytotoxicity of the compounds in 3D multicellular tumor spheroids (MCTS) was assessed by measurement of the ATP concentration. MCTS were treated with increasing concentrations of the compound by replacing $50 \%$ of the media with drug supplemented media and incubation for $12 \mathrm{~h}$. After this time, the MCTS were divided in two identical groups. The first group was strictly kept in the dark. The second group was exposed to light with an Atlas Photonics LUMOS BIO irradiator. Each well was constantly illuminated with either a at $480 \mathrm{~nm}$ (spectral half-width: 20 $\mathrm{nm}, 10 \mathrm{~min}, 3.1 \mathrm{~J} / \mathrm{cm}^{2}$ ) or $595 \mathrm{~nm}$ (spectral half-width: $20 \mathrm{~nm}, 60 \mathrm{~min}, 11.3 \mathrm{~J} / \mathrm{cm}^{2}$ ) irradiation. During this time, the temperature was maintained constantly at $37^{\circ} \mathrm{C}$. The cells were grown in the incubator for additional $48 \mathrm{~h}$. The ATP concertation was measured using a CellTiter-Glo 3D Cell Viability kit (Promega) by measuring the generated chemiluminescence with SpectraMax M2 Microplate Reader (Molecular Devices). The obtained data was analyzed with the GraphPad Prism software.

\section{ASSOCIATED CONTENT}




\section{Supporting Information.}

The Supporting Information is available free of charge at https://pubs.acs.org/doi/XXX.

HPLC chromatogram of $\mathbf{R u}$, Size distribution of NP measured by dynamic light scattering (DLS), Normalised absorption spectra of Ru and NP, Normalised emission spectra of Ru and NP, Lifetime of $\mathbf{R u}$ and $\mathbf{N P}$ in air saturated and degassed $\mathrm{H}_{2} \mathrm{O}$, Lifetime spectra of $\mathbf{R u}$ in air saturated and degassed $\mathrm{H}_{2} \mathrm{O}$, Lifetime spectra of NP in air saturated and degassed $\mathrm{H}_{2} \mathrm{O}$, Singlet oxygen quantum yields of $\mathbf{R u}$ and $\mathbf{N P}$ in $\mathrm{H}_{2} \mathrm{O}$ upon irradiation at $450 \mathrm{~nm}$ or $540 \mathrm{~nm}$, Absorption spectra upon incubation of NP in $\mathrm{H}_{2} \mathrm{O}$ in the dark, Size distribution measured by DLS of NP upon incubation in $\mathrm{H}_{2} \mathrm{O}$ in the dark

Molecular strings formula

\section{AUTHOR INFORMATION}

\section{Corresponding Author}

*gilles.gasser@chimieparistech.psl.eu; Tel. +33 18578 41 51; WWW: www.gassergroup.com.

\section{ORCID}

Johannes Karges: 0000-0001-5258-0260

Gilles Gasser: 0000-0002-4244-5097

\section{Notes}

The authors declare no competing financial interest.

\section{Author Contributions}


J.K. and G.G. were involved with the design and interpretation of experiments and with the writing of the manuscript. Chemical, photophysical and biological experiments were carried out by J.K. ICP-MS measurements were carried out by J.K. and M.T. All authors have given approval to the final version of the manuscript.

\section{ACKNOWLEDGMENT}

We thank Dr. Philippe Goldner for access to state-of-the-art laser apparatus and Dr. Grégory Lefèvre for access to apparatus for the particle characterization. The authors thank Dr. Robin Vinck for helpful discussion. This work was financially supported by an ERC Consolidator Grant PhotoMedMet to G.G. (GA 681679), has received support under the program "Investissements d' Avenir" launched by the French Government and implemented by the ANR with the reference ANR-10-IDEX-0001-02 PSL (G.G.).

\section{ABBREVIATIONS}

A2780, human ovarian carcinoma; A2780 CIS, cisplatin resistant human ovarian carcinoma; A2780 ADR, doxorubicin resistant human ovarian carcinoma; DLS, dynamic light scattering; DSPE-PEG2000-folate, 1,2-distearoyl-sn-glycero-3-phosphoethanolamine- $N$-[folate(polyethylene glycol)-2000][ammonium salt]; EPR, enhanced permeation and retention effect; ICP-MS, inductively coupled plasma mass spectrometry; MCTS, multicellular tumor spheroid; MRC-5, human normal lung fibroblast; NP, nanoparticle formulation of Ru with DSPE-PEG2000-folate; ${ }^{1} \mathrm{O}_{2}$, singlet oxygen; PDT, photodynamic therapy; PI, phototoxic index; PS, photosensitizer; Ru, 
$\left[\mathrm{Ru}(4,7\right.$-diphenyl-1,10-phenanthroline)2(4,4'-dimethyl-2,2'-bipyridine) $]\left[\mathrm{PF}_{6}\right] 2 ; \Phi$, luminescence quantum yield; $\Phi_{102}$, singlet oxygen quantum yield; $\tau$, lifetime.

\section{REFERENCES}

1. Bray, F.; Ferlay, J.; Soerjomataram, I.; Siegel, R. L.; Torre, L. A.; Jemal, A., Global Cancer Statistics 2018: GLOBOCAN Estimates Of Incidence And Mortality Worldwide For 36 Cancers In 185 Countries. CA Cancer J. Clin. 2018, 68, 394-424.

2. Urruticoechea, A.; Alemany, R.; Balart, J.; Villanueva, A.; Vinals, F.; Capella, G., Recent Advances In Cancer Therapy: An Overview. Curr. Pharm. Des. 2010, 16, 3-10.

3. Johnstone, T. C.; Suntharalingam, K.; Lippard, S. J., The Next Generation Of Platinum Drugs: Targeted Pt(II) Agents, Nanoparticle Delivery, And Pt(IV) Prodrugs. Chem. Rev. 2016, $116,3436-3486$.

4. Jamieson, E. R.; Lippard, S. J., Structure, Recognition, And Processing of Cisplatin-DNA Adducts. Chem. Rev. 1999, 99, 2467-2498.

5. Allardyce, C. S.; Dorcier, A.; Scolaro, C.; Dyson, P. J., Development Of Organometallic (Organo-transition Metal) Pharmaceuticals. Appl. Organomet. Chem. 2005, 19, 1-10.

6. Dyson, P. J.; Sava, G., Metal-Based Antitumour Drugs In The Post Genomic Era. Dalton Trans. 2006, 1929-1933.

7. Petruzzella, E.; Sirota, R.; Solazzo, I.; Gandin, V.; Gibson, D., Triple Action Pt(IV)

Derivatives Of Cisplatin: A New Class Of Potent Anticancer Agents That Overcome Resistance. Chem. Sci. 2018, 9, 4299-4307.

8. Yempala, T.; Babu, T.; Karmakar, S.; Nemirovski, A.; Ishan, M.; Gandin, V.; Gibson, D., Expanding The Arsenal Of PtIV Anticancer Agents: Multi-Action PtIV Anticancer Agents With 
Bioactive Ligands Possessing A Hydroxy Functional Group. Angew. Chem. Int. Ed. 2019, 58, $18218-18223$.

9. Liu, F.-S., Mechanisms Of Chemotherapeutic Drug Resistance In Cancer Therapy - A Quick Review. Taiwan J. Obstet. Gynecol. 2009, 48, 239-244.

10. Vasan, N.; Baselga, J.; Hyman, D. M., A View On Drug Resistance In Cancer. Nature 2019, 575, 299-309.

11. Goldie, J. H.; Coldman, A. J., The Genetic Origin Of Drug Resistance In Neoplasms: Implications For Systemic Therapy. Cancer Res. 1984, 44, 3643-3653.

12. Karges, J.; Yempala, T.; Tharaud, M.; Gibson, D.; Gasser, G., A Multi-Action And Multi-Target RuII-PtIV Conjugate Combining Cancer-Activated Chemotherapy And Photodynamic Therapy To Overcome Drug Resistant Cancers. Angew. Chem. Int. Ed. 2020, 59, 7069-7075.

13. McFarland, S. A.; Mandel, A.; Dumoulin-White, R.; Gasser, G., Metal-Based Photosensitizers For Photodynamic Therapy: The Future Of Multimodal Oncology? Curr. Opin. Chem. Biol. 2020, 56, 23-27.

14. Bonnet, S., Why Develop Photoactivated Chemotherapy? Dalton Trans. 2018, 47, 1033010343

15. Dolmans, D. E. J. G. J.; Fukumura, D.; Jain, R. K., Photodynamic Therapy For Cancer. Nat. Rev. Cancer 2003, 3, 380-387.

16. Heinemann, F.; Karges, J.; Gasser, G., Critical Overview Of The Use Of Ru(II) Polypyridyl Complexes As Photosensitizers In One-Photon And Two-Photon Photodynamic Therapy. Acc. Chem. Res. 2017, 50, 2727-2736. 
17. Callaghan, S.; Senge, M. O., The Good, The Bad, And The Ugly - Controlling Singlet Oxygen Through Design Of Photosensitizers And Delivery Systems For Photodynamic Therapy. Photochem. Photobiol. Sci. 2018, 17, 1490-1514.

18. Dumoulin, F., Perfect Photosensitisers? More Than Ever An Exciting Challenge! Photodiagnosis Photodyn. Ther. 2017, 17, A4.

19. Lo, P.-C.; Rodríguez-Morgade, M. S.; Pandey, R. K.; Ng, D. K. P.; Torres, T.; Dumoulin, F., The Unique Features And Promises Of Phthalocyanines As Advanced Photosensitisers For Photodynamic Therapy Of Cancer. Chem. Soc. Rev. 2020, 49, 1041-1056.

20. Lo, K. K.-W., Luminescent Rhenium(I) And Iridium(III) Polypyridine Complexes As Biological Probes, Imaging Reagents, And Photocytotoxic Agents. Acc. Chem. Res. 2015, 48, 2985-2995.

21. Farrer, N. J.; Salassa, L.; Sadler, P. J., Photoactivated Chemotherapy (PACT): The Potential Of Excited-State D-Block Metals In Medicine. Dalton Trans. 2009, 10690-10701. 22. Monro, S.; Colón, K. L.; Yin, H.; Roque, J.; Konda, P.; Gujar, S.; Thummel, R. P.; Lilge, L.; Cameron, C. G.; McFarland, S. A., Transition Metal Complexes And Photodynamic Therapy From A Tumor-Centered Approach: Challenges, Opportunities, And Highlights From The Development of TLD1433. Chem. Rev. 2019, 119, 797-828.

23. Shi, G.; Monro, S.; Hennigar, R.; Colpitts, J.; Fong, J.; Kasimova, K.; Yin, H.; DeCoste, R.; Spencer, C.; Chamberlain, L.; Mandel, A.; Lilge, L.; McFarland, S. A., Ru(II) Dyads Derived From $\alpha$-Oligothiophenes: A New Class Of Potent And Versatile Photosensitizers For PDT.

Coord. Chem. Rev. 2015, 282-283, 127-138. 
24. Knoll, J. D.; Turro, C., Control And Utilization Of Ruthenium And Rhodium Metal Complex Excited States For Photoactivated Cancer Therapy. Coord. Chem. Rev. 2015, 282-283, $110-126$.

25. Li, A.; Turro, C.; Kodanko, J. J., Ru(II) Polypyridyl Complexes Derived From Tetradentate Ancillary Ligands For Effective Photocaging. Acc. Chem. Res. 2018, 51, 14151421.

26. Dickerson, M.; Sun, Y.; Howerton, B.; Glazer, E. C., Modifying Charge And Hydrophilicity Of Simple Ru(II) Polypyridyl Complexes Radically Alters Biological Activities: Old Complexes, Surprising New Tricks. Inorg. Chem. 2014, 53, 10370-10377.

27. Howerton, B. S.; Heidary, D. K.; Glazer, E. C., Strained Ruthenium Complexes Are Potent Light-Activated Anticancer Agents. J. Am. Chem. Soc. 2012, 134, 8324-8327.

28. Karges, J.; Heinemann, F.; Maschietto, F.; Patra, M.; Blacque, O.; Ciofini, I.; Spingler, B.; Gasser, G., A Ru(II) Polypyridyl Complex Bearing Aldehyde Functions As A Versatile Synthetic Precursor For Long-Wavelength Absorbing Photodynamic Therapy Photosensitizers. Bioorg. Med. Chem. 2019, 27, 2666-2675.

29. Fong, J.; Kasimova, K.; Arenas, Y.; Kaspler, P.; Lazic, S.; Mandel, A.; Lilge, L., A Novel Class Of Ruthenium-Based Photosensitizers Effectively Kills In Vitro Cancer Cells And In Vivo Tumors. Photochem. Photobiol. Sci. 2015, 14, 2014-2023.

30. Kaspler, P.; Lazic, S.; Forward, S.; Arenas, Y.; Mandel, A.; Lilge, L., A Ruthenium(ii) Based Photosensitizer And Transferrin Complexes Enhance Photo-Physical Properties, Cell Uptake, And Photodynamic Therapy Safety And Efficacy. Photochem. Photobiol. Sci. 2016, 15, $481-495$. 
31. Lilge, L., Use Of Ruthenium Complexes As Photosensitizers In Photodynamic Therapy. In Ruthenium Complexes, 2018; pp 117-137.

32. Yellol, J.; Pérez, S. A.; Buceta, A.; Yellol, G.; Donaire, A.; Szumlas, P.; Bednarski, P. J.; Makhloufi, G.; Janiak, C.; Espinosa, A.; Ruiz, J., Novel C,N-Cyclometalated Benzimidazole Ruthenium(II) And Iridium(III) Complexes As Antitumor And Antiangiogenic Agents: A Structure-Activity Relationship Study. J. Med. Chem. 2015, 58, 7310-7327.

33. Karges, J., Combining Inorganic Chemistry And Biology: The Underestimated Potential Of Metal Complexes In Medicine. ChemBioChem 2020, 21, 3044-3046.

34. Brissos, R. F.; Clavero, P.; Gallen, A.; Grabulosa, A.; Barrios, L. A.; Caballero, A. B.; Korrodi-Gregório, L.; Pérez-Tomás, R.; Muller, G.; Soto-Cerrato, V.; Gamez, P., Highly Cytotoxic Ruthenium(II)-Arene Complexes From Bulky 1-Pyrenylphosphane Ligands. Inorg. Chem. 2018, 57, 14786-14797.

35. Poynton, F. E.; Bright, S. A.; Blasco, S.; Williams, D. C.; Kelly, J. M.; Gunnlaugsson, T., The Development Of Ruthenium(ii) Polypyridyl Complexes And Conjugates For In Vitro Cellular And In Vivo Applications. Chem. Soc. Rev. 2017, 46, 7706-7756.

36. Karges, J.; Chao, H.; Gasser, G., Critical Discussion Of The Applications Of Metal Complexes For 2-Photon Photodynamic Therapy. J. Biol. Inorg. Chem. 2020, 25, 1035-1050.

37. Elmes, R. B. P.; Orange, K. N.; Cloonan, S. M.; Williams, D. C.; Gunnlaugsson, T., Luminescent Ruthenium(II) Polypyridyl Functionalized Gold Nanoparticles; Their DNA Binding Abilities And Application As Cellular Imaging Agents. J. Am. Chem. Soc. 2011, 133, 1586215865.

38. Imberti, C.; Zhang, P.; Huang, H.; Sadler, P. J., New Designs For Phototherapeutic Transition Metal Complexes. Angew. Chem. Int. Ed. 2020, 59, 61-73. 
39. Felder, P. S.; Keller, S.; Gasser, G., Polymetallic Complexes For Applications As Photosensitisers In Anticancer Photodynamic Therapy. Adv. Therap. 2020, 3, 1900139. 40. Jarman, P. J.; Noakes, F.; Fairbanks, S.; Smitten, K.; Griffiths, I. K.; Saeed, H. K.; Thomas, J. A.; Smythe, C., Exploring The Cytotoxicity, Uptake, Cellular Response, And Proteomics Of Mono- And Dinuclear DNA Light-Switch Complexes. J. Am. Chem. Soc. 2019, $141,2925-2937$.

41. Bonnet, S., Shifting The Light Activation Of Metallodrugs To The Red And NearInfrared Region In Anticancer Phototherapy. Comments Inorg. Chem. 2015, 35, 179-213. 42. Karges, J.; Blacque, O.; Goldner, P.; Chao, H.; Gasser, G., Towards Long Wavelength Absorbing Photodynamic Therapy Photosensitizers Via The Extension Of A [Ru(bipy)3]2+ Core. Eur. J. Inorg. Chem. 2019, 2019, 3704-3712.

43. Novohradsky, V.; Rovira, A.; Hally, C.; Galindo, A.; Vigueras, G.; Gandioso, A.; Svitelova, M.; Bresolí-Obach, R.; Kostrhunova, H.; Markova, L.; Kasparkova, J.; Nonell, S.; Ruiz, J.; Brabec, V.; Marchán, V., Towards Novel Photodynamic Anticancer Agents Generating Superoxide Anion Radicals: A Cyclometalated IrIII Complex Conjugated To A Far-Red Emitting Coumarin. Angew. Chem. Int. Ed. 2019, 58, 6311-6315.

44. Karges, J.; Kuang, S.; Maschietto, F.; Blacque, O.; Ciofini, I.; Chao, H.; Gasser, G., Rationally Designed Ruthenium Complexes For 1- And 2-Photon Photodynamic Therapy. Nat. Commun. 2020, 11, 3262.

45. Raza, A.; Archer, S. A.; Fairbanks, S. D.; Smitten, K. L.; Botchway, S. W.; Thomas, J. A.; MacNeil, S.; Haycock, J. W., A Dinuclear Ruthenium(II) Complex Excited By Near-Infrared Light Through Two-Photon Absorption Induces Phototoxicity Deep Within Hypoxic Regions Of Melanoma Cancer Spheroids. J. Am. Chem. Soc. 2020, 142, 4639-4647. 
46. Ogawa, K.; Kobuke, Y., Recent Advances In Two-Photon Photodynamic Therapy. AntiCancer Agents Med. Chem. 2008, 8, 269-279.

47. Wilson, B. C.; Jeeves, W. P.; Lowe, D. M., In Vivo And Post Mortem Measurments Of The Attenuation Spectra Of Light In Mammalian Tissues. Photochem. Photobiol. 1985, 42, 153162.

48. Karges, J.; Heinemann, F.; Jakubaszek, M.; Maschietto, F.; Subecz, C.; Dotou, M.; Vinck, R.; Blacque, O.; Tharaud, M.; Goud, B.; Viñuelas Zahínos, E.; Spingler, B.; Ciofini, I.; Gasser, G., Rationally Designed Long-Wavelength Absorbing Ru(II) Polypyridyl Complexes As Photosensitizers For Photodynamic Therapy. J. Am. Chem. Soc. 2020, 142, 6578-6587.

49. Wang, T.; Zabarska, N.; Wu, Y.; Lamla, M.; Fischer, S.; Monczak, K.; Ng, D. Y. W.; Rau, S.; Weil, T., Receptor Selective Ruthenium-Somatostatin Photosensitizer For Cancer Targeted Photodynamic Applications. Chem. Commun. 2015, 51, 12552-12555.

50. Barragán, F.; López-Senín, P.; Salassa, L.; Betanzos-Lara, S.; Habtemariam, A.; Moreno, V.; Sadler, P. J.; Marchán, V., Photocontrolled DNA Binding Of A Receptor-Targeted Organometallic Ruthenium(II) Complex. J. Am. Chem. Soc. 2011, 133, 14098-14108.

51. Zhao, Z.; Zhang, X.; Li, C.-e.; Chen, T., Designing Luminescent Ruthenium Prodrug For Precise Cancer Therapy And Rapid Clinical Diagnosis. Biomaterials 2019, 192, 579-589.

52. Paul, S.; Kundu, P.; Bhattacharyya, U.; Garai, A.; Maji, R. C.; Kondaiah, P.; Chakravarty, A. R., Ruthenium(II) Conjugates Of Boron-Dipyrromethene And Biotin For Targeted Photodynamic Therapy In Red Light. Inorg. Chem. 2020, 59, 913-924.

53. Xiang, H.-J.; Deng, Q.; An, L.; Guo, M.; Yang, S.-P.; Liu, J.-G., Tumor Cell Specific And Lysosome-Targeted Delivery Of Nitric Oxide For Enhanced Photodynamic Therapy Triggered By 808 nm Near-Infrared Light. Chem. Commun. 2016, 52, 148-151. 
54. Zhao, X.; Li, M.; Sun, W.; Fan, J.; Du, J.; Peng, X., An Estrogen Receptor Targeted Ruthenium Complex As A Two-Photon Photodynamic Therapy Agent For Breast Cancer Cells. Chem. Commun. 2018, 54, 7038-7041.

55. Jakubaszek, M.; Rossier, J.; Karges, J.; Delasoie, J.; Goud, B.; Gasser, G.; Zobi, F., Evaluation Of The Potential Of Cobalamin Derivatives Bearing Ru(II) Polypyridyl Complexes As Photosensitizers For Photodynamic Therapy. Helv. Chim. Acta 2019, 102, e1900104.

56. Du, E.; Hu, X.; Roy, S.; Wang, P.; Deasy, K.; Mochizuki, T.; Zhang, Y., TaurineModified Ru(ii)-Complex Targets Cancerous Brain Cells For Photodynamic Therapy. Chem. Commun. 2017, 53, 6033-6036.

57. Lameijer, L. N.; Hopkins, S. L.; Brevé, T. G.; Askes, S. H. C.; Bonnet, S., D- Versus LGlucose Conjugation: Mitochondrial Targeting Of A Light-Activated Dual-Mode-Of-Action Ruthenium-Based Anticancer Prodrug. Chem. Eur. J. 2016, 22, 18484-18491.

58. Fu, H.-G.; Chen, Y.; Yu, Q.; Liu, Y., A Tumor-Targeting Ru/Polysaccharide/Protein Supramolecular Assembly With High Photodynamic Therapy Ability. Chem. Commun. 2019, 55, $3148-3151$.

59. Karges, J.; Jakubaszek, M.; Mari, C.; Zarschler, K.; Goud, B.; Stephan, H.; Gasser, G., Synthesis And Characterization Of An Epidermal Growth Factor Receptor-Selective RuII Polypyridyl-Nanobody Conjugate As A Photosensitizer For Photodynamic Therapy. ChemBioChem 2020, 21, 531-542.

60. Huang, Y.; Huang, W.; Chan, L.; Zhou, B.; Chen, T., A Multifunctional DNA Origami As Carrier Of Metal Complexes To Achieve Enhanced Tumoral Delivery And Nullified Systemic Toxicity. Biomaterials 2016, 103, 183-196. 
61. Zhu, X.; Zhou, H.; Liu, Y.; Wen, Y.; Wei, C.; Yu, Q.; Liu, J., Transferrin/Aptamer Conjugated Mesoporous Ruthenium Nanosystem For Redox-Controlled And Targeted ChemoPhotodynamic Therapy Of Glioma. Acta Biomater. 2018, 82, 143-157.

62. Chakrabortty, S.; Agrawalla, B. K.; Stumper, A.; Vegi, N. M.; Fischer, S.; Reichardt, C.;

Kögler, M.; Dietzek, B.; Feuring-Buske, M.; Buske, C.; Rau, S.; Weil, T., Mitochondria Targeted Protein-Ruthenium Photosensitizer For Efficient Photodynamic Applications. J. Am. Chem. Soc. 2017, 139, 2512-2519.

63. Shi, H.; Fang, T.; Tian, Y.; Huang, H.; Liu, Y., A Dual-Fluorescent Nano-Carrier For Delivering Photoactive Ruthenium Polypyridyl Complexes. J. Mater. Chem. B 2016, 4, 47464753.

64. Arora, K.; Herroon, M.; Al-Afyouni, M. H.; Toupin, N. P.; Rohrabaugh, T. N.; Loftus, L. M.; Podgorski, I.; Turro, C.; Kodanko, J. J., Catch And Release Photosensitizers: Combining Dual-Action Ruthenium Complexes With Protease Inactivation For Targeting Invasive Cancers. J. Am. Chem. Soc. 2018, 140, 14367-14380.

65. Sun, D.; Liu, Y.; Yu, Q.; Zhou, Y.; Zhang, R.; Chen, X.; Hong, A.; Liu, J., The Effects Of Luminescent Ruthenium(II) Polypyridyl Functionalized Selenium Nanoparticles On bFGFInduced Angiogenesis And AKT/ERK Signaling. Biomaterials 2013, 34, 171-180.

66. Liu, T.; Zeng, L.; Jiang, W.; Fu, Y.; Zheng, W.; Chen, T., Rational Design Of CancerTargeted Selenium Nanoparticles To Antagonize Multidrug Resistance In Cancer Cells. Nanomedicine 2015, 11, 947-958.

67. Sun, D.; Liu, Y.; Yu, Q.; Qin, X.; Yang, L.; Zhou, Y.; Chen, L.; Liu, J., Inhibition Of Tumor Growth And Vasculature And Fluorescence Imaging Using Functionalized RutheniumThiol Protected Selenium Nanoparticles. Biomaterials 2014, 35, 1572-1583. 
68. Wumaier, M.; Yao, T.-M.; Hu, X.-C.; Hu, Z.-A.; Shi, S., Luminescent Ru(II)-Thiol Modified Silver Nanoparticles For Lysosome Targeted Theranostics. Dalton Trans. 2019, 48, 10393-10397.

69. Zhang, P.; Wang, J.; Huang, H.; Chen, H.; Guan, R.; Chen, Y.; Ji, L.; Chao, H., RuNH2@AuNPs As Two-Photon Luminescent Probes For Thiols In Living Cells And Tissues. Biomaterials 2014, 35, 9003-9011.

70. $\quad$ Rogers, N. J.; Claire, S.; Harris, R. M.; Farabi, S.; Zikeli, G.; Styles, I. B.; Hodges, N. J.; Pikramenou, Z., High Coating Of Ru(ii) Complexes On Gold Nanoparticles For Single Particle Luminescence Imaging In Cells. Chem. Commun. 2014, 50, 617-619.

71. Frasconi, M.; Liu, Z.; Lei, J.; Wu, Y.; Strekalova, E.; Malin, D.; Ambrogio, M. W.; Chen, X.; Botros, Y. Y.; Cryns, V. L.; Sauvage, J.-P.; Stoddart, J. F., Photoexpulsion Of SurfaceGrafted Ruthenium Complexes And Subsequent Release Of Cytotoxic Cargos To Cancer Cells From Mesoporous Silica Nanoparticles. J. Am. Chem. Soc. 2013, 135, 11603-11613.

72. Knežević, N. Ž.; Stojanovic, V.; Chaix, A.; Bouffard, E.; Cheikh, K. E.; Morère, A.; Maynadier, M.; Lemercier, G.; Garcia, M.; Gary-Bobo, M.; Durand, J.-O.; Cunin, F., Ruthenium(ii) Complex-Photosensitized Multifunctionalized Porous Silicon Nanoparticles For Two-Photon Near-Infrared Light Responsive Imaging And Photodynamic Cancer Therapy. J. Mater. Chem. B 2016, 4, 1337-1342.

73. He, L.; Huang, Y.; Zhu, H.; Pang, G.; Zheng, W.; Wong, Y.-S.; Chen, T., CancerTargeted Monodisperse Mesoporous Silica Nanoparticles As Carrier Of Ruthenium Polypyridyl Complexes To Enhance Theranostic Effects. Adv. Funct. Mater. 2014, 24, 2754-2763.

74. Ellahioui, Y.; Patra, M.; Mari, C.; Kaabi, R.; Karges, J.; Gasser, G.; Gómez-Ruiz, S., Mesoporous Silica Nanoparticles Functionalised With A Photoactive Ruthenium(ii) Complex: 
Exploring The Formulation Of A Metal-Based Photodynamic Therapy Photosensitiser. Dalton Trans. 2019, 48, 5940-5951.

75. Wen, J.; Yan, H.; Xia, P.; Xu, Y.; Li, H.; Sun, S., Mesoporous Silica NanoparticlesAssisted Ruthenium(II) Complexes For Live Cell Staining. Sci. China Chem. 2017, 60, 799-805. 76. Chen, Y.; Jiang, G.; Zhou, Q.; Zhang, Y.; Li, K.; Zheng, Y.; Zhang, B.; Wang, X., An Upconversion Nanoparticle/Ru(ii) Polypyridyl Complex Assembly For NIR-Activated Release Of A DNA Covalent-Binding Agent. RSC Adv. 2016, 6, 23804-23808.

77. Soliman, N.; Gasser, G.; Thomas, C. M., Incorporation Of Ru(II) Polypyridyl Complexes Into Nanomaterials For Cancer Therapy And Diagnosis. Adv. Mater. 2020, 2003294.

78. Meijer, M. S.; Natile, M. M.; Bonnet, S., 796 nm Activation Of A Photocleavable Ruthenium(II) Complex Conjugated To An Upconverting Nanoparticle Through Two Phosphonate Groups. Inorg. Chem. 2020, 59, 14807-14818.

79. Bœuf, G.; Roullin, G. V.; Moreau, J.; Van Gulick, L.; Zambrano Pineda, N.; Terryn, C.; Ploton, D.; Andry, M. C.; Chuburu, F.; Dukic, S.; Molinari, M.; Lemercier, G., Encapsulated Ruthenium(II) Complexes In Biocompatible Poly(d,l-lactide-co-glycolide) Nanoparticles For Application In Photodynamic Therapy. ChemPlusChem 2014, 79, 171-180.

80. Soliman, N.; McKenzie, L. K.; Karges, J.; Bertrand, E.; Tharaud, M.; Jakubaszek, M.; Guérineau, V.; Goud, B.; Hollenstein, M.; Gasser, G.; Thomas, C. M., Ruthenium-Initiated Polymerization Of Lactide: A Route To Remarkable Cellular Uptake For Photodynamic Therapy Of Cancer. Chem. Sci. 2020, 11, 2657-2663.

81. Maggioni, D.; Fenili, F.; D’Alfonso, L.; Donghi, D.; Panigati, M.; Zanoni, I.; Marzi, R.; Manfredi, A.; Ferruti, P.; D’Alfonso, G.; Ranucci, E., Luminescent Rhenium And Ruthenium 
Complexes Of An Amphoteric Poly(amidoamine) Functionalized With 1,10-Phenanthroline. Inorg. Chem. 2012, 51, 12776-12788.

82. Chan, L.; Huang, Y.; Chen, T., Cancer-Targeted Tri-Block Copolymer Nanoparticles As Payloads Of Metal Complexes To Achieve Enhanced Cancer Theranosis. J. Mater. Chem. B 2016, 4, 4517-4525.

83. Karges, J.; Chao, H.; Gasser, G., Synthesis, Characterization, And Biological Evaluation Of The Polymeric Encapsulation Of A Ruthenium(II) Polypyridine Complex With Pluronic F127/Poloxamer-407 For Photodynamic Therapy Applications. Eur. J. Inorg. Chem. 2020, 2020, $3242-3248$.

84. Mascheroni, L.; Dozzi, M. V.; Ranucci, E.; Ferruti, P.; Francia, V.; Salvati, A.; Maggioni, D., Tuning Polyamidoamine Design To Increase Uptake And Efficacy Of Ruthenium Complexes For Photodynamic Therapy. Inorg. Chem. 2019, 58, 14586-14599.

85. Sun, W.; Li, S.; Häupler, B.; Liu, J.; Jin, S.; Steffen, W.; Schubert, U. S.; Butt, H.-J.;

Liang, X.-J.; Wu, S., An Amphiphilic Ruthenium Polymetallodrug For Combined Photodynamic Therapy And Photochemotherapy In Vivo. Adv. Mater. 2017, 29, 1603702.

86. Soliman, N.; Sol, V.; Ouk, T.-S.; Thomas, C. M.; Gasser, G., Encapsulation Of A Ru (II) Polypyridyl Complex Into Polylactide Nanoparticles For Antimicrobial Photodynamic Therapy. Pharmaceutics 2020, 12, 961.

87. Chen, B.; Metera, K.; Sleiman, H. F., Biotin-Terminated Ruthenium Bipyridine RingOpening Metathesis Polymerization Copolymers: Synthesis And Self-Assembly With Streptavidin. Macromolecules 2005, 38, 1084-1090. 
88. Ruggi, A.; Beekman, C.; Wasserberg, D.; Subramaniam, V.; Reinhoudt, D. N.; van Leeuwen, F. W. B.; Velders, A. H., Dendritic Ruthenium(II)-Based Dyes Tuneable For Diagnostic Or Therapeutic Applications. Chem. Eur. J. 2011, 17, 464-467.

89. Shen, J.; Kim, H.-C.; Wolfram, J.; Mu, C.; Zhang, W.; Liu, H.; Xie, Y.; Mai, J.; Zhang, H.; Li, Z.; Guevara, M.; Mao, Z.-W.; Shen, H., A Liposome Encapsulated Ruthenium Polypyridine Complex As A Theranostic Platform For Triple-Negative Breast Cancer. Nano Lett. 2017, 17, 2913-2920.

90. Askes, S. H. C.; Bahreman, A.; Bonnet, S., Activation Of A Photodissociative Ruthenium Complex By Triplet-Triplet Annihilation Upconversion In Liposomes. Angew. Chem. Int. Ed. 2014, 53, 1029-1033.

91. Zhang, D.-Y.; Zheng, Y.; Tan, C.-P.; Sun, J.-H.; Zhang, W.; Ji, L.-N.; Mao, Z.-W., Graphene Oxide Decorated With Ru(II)-Polyethylene Glycol Complex For Lysosome-Targeted Imaging And Photodynamic/Photothermal Therapy. ACS Appl. Mater. Interfaces 2017, 9, 67616771.

92. Wang, N.; Feng, Y.; Zeng, L.; Zhao, Z.; Chen, T., Functionalized Multiwalled Carbon Nanotubes As Carriers Of Ruthenium Complexes To Antagonize Cancer Multidrug Resistance And Radioresistance. ACS Appl. Mater. Interfaces 2015, 7, 14933-14945.

93. Zhang, P.; Huang, H.; Huang, J.; Chen, H.; Wang, J.; Qiu, K.; Zhao, D.; Ji, L.; Chao, H., Noncovalent Ruthenium(II) Complexes-Single-Walled Carbon Nanotube Composites For Bimodal Photothermal And Photodynamic Therapy With Near-Infrared Irradiation. ACS Appl. Mater. Interfaces 2015, 7, 23278-23290.

94. Zhang, W.; Li, B.; Ma, H.; Zhang, L.; Guan, Y.; Zhang, Y.; Zhang, X.; Jing, P.; Yue, S., Combining Ruthenium(II) Complexes With Metal-Organic Frameworks To Realize Effective 
Two-Photon Absorption For Singlet Oxygen Generation. ACS Appl. Mater. Interfaces 2016, 8, $21465-21471$.

95. Chen, R.; Zhang, J.; Chelora, J.; Xiong, Y.; Kershaw, S. V.; Li, K. F.; Lo, P.-K.; Cheah, K. W.; Rogach, A. L.; Zapien, J. A.; Lee, C.-S., Ruthenium(II) Complex Incorporated UiO-67 Metal-Organic Framework Nanoparticles For Enhanced Two-Photon Fluorescence Imaging And Photodynamic Cancer Therapy. ACS Appl. Mater. Interfaces 2017, 9, 5699-5708.

96. Danhier, F., To Exploit The Tumor Microenvironment: Since The EPR Effect Fails In The Clinic, What Is The Future Of Nanomedicine? J. Control. Release 2016, 244, 108-121. 97. Karges, J.; Li, J.; Zeng, L.; Chao, H.; Gasser, G., Polymeric Encapsulation Of A Ruthenium Polypyridine Complex For Tumor Targeted 1- And 2-Photon Photodynamic Therapy. ACS Appl. Mater. Interfaces 2020, 12, 54433-54444.

98. Leamon, C. P.; Low, P. S., Folate-Mediated Targeting: From Diagnostics To Drug And Gene Delivery. Drug Discov. Today 2001, 6, 44-51.

99. Hilgenbrink, A. R.; Low, P. S., Folate Receptor-Mediated Drug Targeting: From Therapeutics To Diagnostics. J. Pharm. Sci. 2005, 94, 2135-2146.

100. Wibowo, A. S.; Singh, M.; Reeder, K. M.; Carter, J. J.; Kovach, A. R.; Meng, W.; Ratnam, M.; Zhang, F.; Dann, C. E., Structures Of Human Folate Receptors Reveal Biological Trafficking States And Diversity In Folate And Antifolate Recognition. Proc. Acad. Natl. Sci. 2013, $110,15180-15188$.

101. Karges, J.; Blacque, O.; Chao, H.; Gasser, G., Polymeric Bis(dipyrrinato) Zinc(II) Nanoparticles As Selective Imaging Probes For Lysosomes of Cancer Cells. Inorg. Chem. 2019, $58,12422-12432$. 
102. Karges, J.; Basu, U.; Blacque, O.; Chao, H.; Gasser, G., Polymeric Encapsulation Of Novel Homoleptic Bis(dipyrrinato) Zinc(II) Complexes With Long Lifetimes For Applications As Photodynamic Therapy Photosensitisers. Angew. Chem. Int. Ed. 2019, 58, 14334-14340.

103. Zang, Q.; Yu, J.; Yu, W.; Qian, J.; Hu, R.; Tang, B. Z., Red-Emissive Azabenzanthrone Derivatives For Photodynamic Therapy Irradiated With Ultralow Light Power Density And Two-Photon Imaging. Chem. Sci. 2018, 9, 5165-5171.

104. Portney, N. G.; Ozkan, M., Nano-Oncology: Drug Delivery, Imaging, And Sensing. Anal. Bioanal. Chem. 2006, 384, 620-630.

105. Villemin, E.; Ong, Y. C.; Thomas, C. M.; Gasser, G., Polymer Encapsulation Of Ruthenium Complexes For Biological And Medicinal Applications. Nat. Rev. Chem. 2019, 3, 261-282.

106. Cook, M. J.; Lewis, A. P.; McAuliffe, G. S. G.; Skarda, V.; Thomson, A. J.; Glasper, J. L.; Robbins, D. J., Luminescent Metal Complexes. Part 1. Tris-Chelates Of Substituted 2,2'bipyridyls With Ruthenium(II) As Dyes For Luminescent Solar Collectors. J. Chem. Soc., Perkin Trans. 2 1984, 1293-1301.

107. Balzani, V.; Juris, A., Photochemistry And Photophysics Of Ru(II) Polypyridine Complexes In The Bologna Group. From Early Studies To Recent Developments. Coord. Chem. Rev. 2001, 211, 97-115.

108. Karges, J.; Blacque, O.; Gasser, G., Metal Dipyrrin Complexes As Potential Photosensitizers For Photodynamic Therapy. Inorg. Chim. Acta 2020, 505, 119482. 109. Karges, J.; Gasser, G., Synthesis, Characterisation And Biological Evaluation Of $\pi$ Extended Fe(II) Bipyridine Complexes As Potential Photosensitizers For Photodynamic Therapy. Inorg. Chim. Acta 2020, 499, 119196. 
110. Khan, A. A.; Fullerton-Shirey, S. K.; Howard, S. S., Easily Prepared RutheniumComplex Nanomicelle Probes For Two-photon Quantitative Imaging Of Oxygen In Aqueous Media. RSC Adv. 2015, 5, 291-300.

111. Renfrew, A. K.; Karges, J.; Scopelliti, R.; Bobbink, F. D.; Nowak-Sliwinska, P.; Gasser, G.; Dyson, P. J., Towards Light-Activated Ruthenium-Arene (RAPTA-Type) Prodrug Candidates. ChemBioChem 2019, 20, 2876-2882.

112. Kovacevic, A.; Savic, S.; Vuleta, G.; Müller, R. H.; Keck, C. M., Polyhydroxy Surfactants For The Formulation Of Lipid Nanoparticles (SLN And NLC): Effects On Size, Physical Stability And Particle Matrix Structure. Int. J. Pharm. 2011, 406, 163-172.

113. Hou, Z.; Gattoc, L.; O'Connor, C.; Yang, S.; Wallace-Povirk, A.; George, C.; Orr, S.; Polin, L.; White, K.; Kushner, J.; Morris, R. T.; Gangjee, A.; Matherly, L. H., Dual Targeting Of Epithelial Ovarian Cancer Via Folate Receptor $\alpha$ And The Proton-Coupled Folate Transporter With 6-Substituted Pyrrolo[2,3-d]pyrimidine Antifolates. Mol. Cancer Ther. 2017, 16, 819-830.

114. Antony, A. C., Folate Receptors. Annu. Rev. Nutr. 1996, 16, 501-521.

115. Yu, Y.; Wang, J.; Kaul, S. C.; Wadhwa, R.; Miyako, E., Folic Acid Receptor-Mediated Targeting Enhances The Cytotoxicity, Efficacy, And Selectivity Of Withania Somnifera Leaf Extract: In Vitro And In Vivo Evidence. Front. Oncol. 2019, 9.

116. Donohoe, C.; Senge, M. O.; Arnaut, L. G.; Gomes-da-Silva, L. C., Cell Death In Photodynamic Therapy: From Oxidative Stress To Anti-Tumor Immunity. Biochim. Biophys. Acta 2019, 1872, 188308.

117. Adams, J. M., Ways Of Dying: Multiple Pathways To Apoptosis. Genes Dev. 2003, 17, 2481-2495. 
118. Qian, C.; Wang, J.-Q.; Song, C.-L.; Wang, L.-L.; Ji, L.-N.; Chao, H., The Induction Of Mitochondria-Mediated Apoptosis In Cancer Cells By Ruthenium(ii) Asymmetric Complexes. Metallomics 2013, 5, 844-854.

119. Huang, H.; Zhang, P.; Yu, B.; Chen, Y.; Wang, J.; Ji, L.; Chao, H., Targeting Nucleus DNA With A Cyclometalated Dipyridophenazineruthenium(II) Complex. J. Med. Chem. 2014, $57,8971-8983$

120. Netti, P. A.; Berk, D. A.; Swartz, M. A.; Grodzinsky, A. J.; Jain, R. K., Role Of Extracellular Matrix Assembly In Interstitial Transport In Solid Tumors. Cancer Res. 2000, 60, 2497-2503.

121. Dyson, P. J., The Rise Of 3D Cellular Spheroids: Efficient Culture Via Upward Growth From A Superamphiphobic Surface. Natl. Sci. Rev. 2019, 6 (-), 1068-1069.

122. Lameijer, L. N.; Ernst, D.; Hopkins, S. L.; Meijer, M. S.; Askes, S. H. C.; Le Dévédec, S. E.; Bonnet, S., A Red-Light-Activated Ruthenium-Caged NAMPT Inhibitor Remains Phototoxic In Hypoxic Cancer Cells. Angew. Chem. Int. Ed. 2017, 56, 11549-11553.

123. Karges, J.; Kuang, S.; Ong, Y. C.; Chao, H.; Gasser, G., One- And Two-Photon Phototherapeutic Effects Of RuII Polypyridine Complexes In The Hypoxic Centre Of Large Multicellular Tumor Spheroids And Tumor-Bearing Mice. Chem. Eur. J. 2021, 27, 362-370. 124. Roque III, J.; Havrylyuk, D.; Barrett, P. C.; Sainuddin, T.; McCain, J.; Colón, K.; Sparks, W. T.; Bradner, E.; Monro, S.; Heidary, D.; Cameron, C. G.; Glazer, E. C.; McFarland, S. A., Strained, Photoejecting Ru(II) Complexes That Are Cytotoxic Under Hypoxic Conditions. Photochem. Photobiol. 2020, 96, 327-339.

125. Friedrich, J.; Seidel, C.; Ebner, R.; Kunz-Schughart, L. A., Spheroid-Based Drug Screen: Considerations And Practical Approach. Nat. Protoc. 2009, 4, 309-324. 
126. Kunz-Schughart, L. A., Multicellular Tumor Spheroids: Intermediates Between Monolayer Culture And In Vivo Tumor. Cell. Biol. Int. 1999, 23, 157-161.

127. Katsumi, N., Solvent Effect On The Nonradiative Deactivation Of The Excited State Of Tris(2,2'-bipyridyl)ruthenium(II) Ion. Bull. Chem. Soc. Jpn. 1982, 55, 1639-1640.

128. Garcìa-Fresnadillo, D.; Georgiadou, Y.; Orellana, G.; Braun, A. M.; Oliveros, E., SingletOxygen $(1 \Delta \mathrm{g})$ Production By Ruthenium(II) Complexes Containing Polyazaheterocyclic Ligands In Methanol And In Water. Helv. Chim. Acta 1996, 79, 1222-1238.

Table of Content (TOC) graphic:
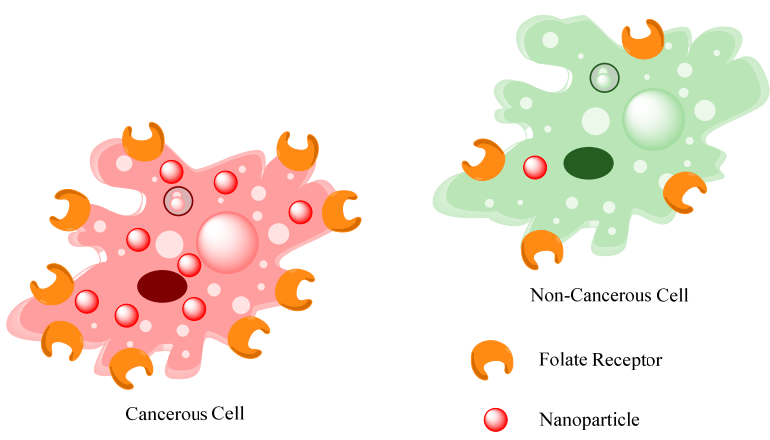